\title{
A língua Moldava nomeia o quê?
}

Patrick Sériot ${ }^{2}$

\begin{abstract}
This study aims to reflect about linguistics policies developed at the East of Europe investigating the problem of competition between Romanian and Moldavian languages. By asking what is inscribed in the action of naming a language and analyzing the specificities and historical arguments presented by Roumanian and Moldavian citizens we try to understand the sources of nationalism in each nation.
\end{abstract}

Keywords: Language: nation; policies, identity.

Resumo: Este estudo propõe uma reflexão em torno das políticas linguísticas desencadeadas no Leste Europeu, investigando o problema das disputas entre as línguas Moldava e Romena. Ao questionar o que se inscreve na ação de nomear uma língua e analisar as especificidades e os argumentos históricos apresentados pelos cidadãos Romenos e Moldavos buscamos compreender as origens do nacionalismo em cada uma das nações.

Palavras-chave: Língua; nação; políticas; identidade.

Não temos necessidade da opinião dos linguistas sobre a denominação da língua que falamos. É a língua moldava, bem mais antiga que a língua romena. (V. Voronin, Presidente da República da Moldávia, dezembro de 2003)

A propagação sob toda forma de uma língua moldava, diferente da língua romena é uma fraude sob um ponto de vista científico, sob um ponto de vista histórico e prático, um absurdo e uma utopia e do ponto de vista prático é a anulação da identidade étnica e cultural de um povo e, portanto, um ato de genocídio etnocultural. (Coseriu 2002:3) ${ }^{3}$

\section{Introdução}

É fato bem conhecido e bastante discutido que o nome da língua da República da Moldávia seja uma questão política ${ }^{4}$. A tese soviética era de que o moldavo é uma língua diferente do Romeno. A tese do romeno era e é ainda que o moldavo não é senão o nome do romeno dado por inimigos políticos. Na Moldávia atual, os partidários da união de Estado com a Romênia ou a integração europeia denominam sua língua de romena, os que preferem uma independência estrita ou uma orientação pró-russa a denominam de moldava. A alternância das maiorias políticas no seio do governo é marcada

1 Este trabalho foi realizado no quadro do projeto $n^{\circ} 16-18-02042$, financiado pelo fundo Rossijskij naučnyl

2 Patrick Sériot é Professor Titular de Língua Russa da Universidade de Lausanne e trabalha como Prof. Visitante na Universidade de São Petersburgo.

3 As duas citações foram extraídas de Lenta, 2004.

4 Ver os trabalhos de Bellet 1997; Bernaz 2016; Bochmann 2013; Bruchis 1996; Cinclei 1996; Dyer 1996, 1999; Kazazis 1982; King 1994, 1995, 1997, 1999; Kleß 1955; Lența 2004; Mullen 1989; Trifon 1999, 2007, 2010. 
por uma mudança no nome da língua de Estado. Assim, entre as correntes pan-romenas e autônomas o bloqueio é total.

O jogo do nome da língua tem um significado ideológico-político, ele é a mola propulsora das ciências políticas e da relação entre o Leste e o Oeste da Europa. É claro que ele não tem nada a ver com a ciência linguística. Não há mais o que dizer. Já que para inúmeros observadores, em particular linguistas como E. Coseriu, trata-se de um problema falso, de um não-acontecimento, sobre o qual não valeria mais a pena refletir ${ }^{5}$. Na verdade, o assunto não é tão simples. Na República da Moldávia (doravante RM) após o entusiasmo com a pró-união com a Romênia que acompanhou a independência em 1989 emergiu uma posição mais circunspecta, independentista, com o retorno de inúmeros quadros do velho regime ao poder em 1994,o que fez com que a nomeação "língua romena" fosse preferencialmente fato de uma inteligência minoritária. Mas o que importa aqui é que a querela onomástica impregna a tal ponto as realidades no território em que caminhamos sobre ovos, que tentar descrever a "questão da língua" da Moldávia é sempre uma questão delicada. Com efeito, por razões políticas, os moldavianos são denominados "romenos" na Romênia (quer se trate da província romena da Moldávia ou da República independente da Moldávia) mas "moldavianos" na RM (sem que tenha havido acordo para saber se este nome concerne unicamente aos moldavianos da República independente, ou igualmente àqueles da Moldávia romena).

\section{Cujus régio, ejus língua}

Poderíamos pensar que nos encontramos diante da oposição de duas concepções de identidade nacional: direito de solo versus direito de sangue, ou seja, por um lado a tese romântica essencialista: em que a identidade se funda sobre a língua e a origem comum,e por outro, a tese jacobina contratualista em que ela repousa sobre o território e a cidadania comum. Ora, não é nada disso, já que os adversários partilham a mesma convicção com uma bela unanimidade de acordo com a qual: uma nação é um povo, e um povo se define por sua língua. E a essa língua é preciso, portanto, dar o nome correto ${ }^{6}$.

Para que a controvérsia onomástica tenha algum sentido, é preciso que se apoie sobre um postulado implícito, jamais exposto ou discutido, isto é, que uma nação define-se por sua língua e que uma língua não pode pertencer a uma única nação. Trata-se de um princípio hegeliano retomado por Stalin em $1913^{7}$ que paradoxalmente sustenta tanto o

5 Ver King 1994: “... o que os Moldavos se denominam e a sua é uma questão política e não linguística”. Kirkhood 1990 "A criação do moldavo como uma língua separada tem mais relação com a política do que com a linguística".

6 É útil comparar a questão da língua na Europa Oriental a um país como a Suíça: para os suíços franceses está claro que: 1) sua língua é o francês; 2) eles não são franceses; 3) o nome de sua língua não coloca nenhum problema de identidade nacional.

7 Lembremos que para Stalin uma nação é "uma comunidade humana estável, historicamente constituída sobre a base de uma comunidade de língua, de território, de vida econômica e de feição psíquica manifestado em uma comunidade de cultura" (Stalin, 1913, pp.). É evidente que a Suíça, a partir desta definição romântico-positivista de Stalin, não pode ser uma nação, ela não é, tanto quanto possível, senão um material etnográfico em permanente construção de uma língua nacional por seus poetas e escritores, e que seja ao contrário um território artificial onde os suíços franceses, componentes do povo francês em terra irredenta, um dia deverão ser inseridos à França-mãe-pátria, mesmo para os germânicos e a Alemanha ou os italianos do Cantão Suíço e a Itália. Os romanches seriam então o núcleo inicial de constituição de uma nação, eventual suíça em torno da base linguística. Este tipo de racionalidade é, em geral, de difícil compreensão para os estudantes francófonos, habituados à definição de cidadania - não etnolinguística - de nação. 
romantismo como o positivismo e que está na base da especificidade do discurso sobre a língua na Europa Oriental, acarretando uma extrema dificuldade de "compreensão".

Objeto desconcertante de uma querela de difícil compreensão, a língua moldava é um fenômeno em que o par causa/consequência torna-se funcional a ponto de transformar-se em um círculo infernal: a tese essencialista em RM tem aqui de particular o fato de que se a língua define supostamente a nação, ao mesmo tempo é o Estado que define a língua. $\mathrm{O}$ imbróglio das definições institui-se de modo proporcional ao simulacro identitário.

$\mathrm{Ou}$, curiosamente, o fato de que os lingüistas profissionais estejam pessoalmente implicados na querela da nomeação passou relativamente despercebido. Uma sub-disciplina aos métodos também rigorosos que a fonologia convocou para sustentar as decisões políticas.

Em nome de um cientificismo para as aparências positivistas, os jogos identitários, afetivos, engajando a vida de milhões de indivíduos, cristalizam-se. Eis o que merece alguns esclarecimentos. Este trabalho diz respeito, então, ao discurso dos linguistas e mais amplamente ao discurso sobre a língua moldava e ao conjunto de argumentos utilizado por cada uma das duas teses ${ }^{9}$.

Gostaríamos de explorar aqui a hipótese de que o discurso sobre a língua na Europa Oriental tem algo a nos ensinar acerca do sujeito "das representações sobre a língua" estando inclusos os profissionais. Sem rejeitar a tese do "todo político" gostaríamos de explorar aqui o aspecto metadiscursivo da querela: de que natureza é o objeto língua na controvérsia onomástica moldaviana? De acordo com meu conhecimento, o aspecto "representação linguística" e não sócio político relativo ao problema do nome moldavo não foi verdadeiramente abordado, seja por rejeição, seja por desconhecimento.

Ao contrário, penso que este modo de cortar os cabelos em quatro partes na querela glotonímica deixa aparecer em filigrana uma questão fundamental para a Linguística:. De que, justamente, se fala quando se toma a língua com objeto de discurso? Onde começa e onde termina uma língua? Quais são os limites? Os linguistas têm algumas coisas para dizer sobre este tema? Tratar-se-á, então, aqui, menos de política da língua do que de política da Linguística.

Será necessário, assim, buscar um quadro de reflexão para não cair na armadilha do discurso militante e avançar com precaução sobre o tema da identidade e da diferença em torno de uma questão semiótica essencial: é a coisa que faz o nome ou o nome que faz a coisa?

Encontramos no "ocidente", a crença na ideia de que o moldavo é o nome russo do romeno falado na Moldávia e de que "o moldavo é uma língua próxima da romena". Agora, se para o lógico G. Frege (1892), não há dúvida de que a estrela da manhã e a estrela da tarde são dois sentidos diferentes para um mesmo referente (o planeta Vênus) é muito menos seguro que os nomes "moldaviano" e "romeno" possam reenviar simplesmente à mesma língua como um referente tão estável e único à semelhança do planeta Vênus, do mesmo modo que não se estabelece o que se entende por língua. A controvérsia pode ser resumida no confronto de duas afirmações ontológicas, duas equações mutuamente exclusivas; o moldavo $(\mathrm{M})$ é/não é o romeno $(\mathrm{R})^{10}$.

8 Me ocorre ter sido dado a entender na ex-União Soviética a ideia de que a Suíça não constitui uma nação porque seus poetas e escritores ainda não elaboravam a língua literária nacional suíça.

9 Manteremos aqui no corpus da produção acadêmica um trabalho à parte, entretanto de mais difícil realização e que deve ser consagrado às conversas de terraço de café, às disputas políticas, aos poemas patrióticos, às cartas de leitores, às redes sociais.

10 Sobre a questão perfeitamente paralela das relações conflitantes entre o búlgaro e o macedônio, ver aqui mesmo P. Sériot: "É preciso que as línguas tenham um nome?” o caso do macedônio. 


$$
\begin{gathered}
M=R \\
M \neq R
\end{gathered}
$$

O discurso sobre a língua, entretanto, não se deixa modular em categorias de lógica binária e entre as duas posições existe uma série de soluções intermediárias. As afirmações peremptórias se tocam, enunciando certezas para além delas, ou a evidência empírica constitui uma demanda argumentativa, permitindo que se passe das provas e dos argumentos

(a) $\mathrm{M}=\mathrm{R} \varnothing$

Moldavianos e romenos são exatamente o mesmo (Kamusella 2015: 14).

Teria sido fácil comparar as gramáticas para concluir que a lingua standard na Romênia e na Moldávia ex-soviética é uma única e mesma língua (A Damian., 2017:sp)

A diferença entre o romeno e o moldavo é pouco perceptível (Dwerski, 2006, 168).

(a') $\mathrm{M}=$ uma pura invenção artificial, projeto maquiavélico

A língua moldava foi construída pela diferença em relação à romena. As populações dos limites da União se atribuem pela escolha do alfabeto e por um trabalho de reflexão lexical e gramatical, as línguas proclamadas como perfeitamente distintas daquelas faladas do outro lado da fronteira: o moldavo é, deste modo, construído pela diferenciação em relação ao romeno (Thiesse 2001: 239).

As propriedades da política linguística mudaram também, mas um tema claro emerge: a língua era manipulada a fim de criar uma identidade étnica para os habitantes, primeiramente o Moldavo ASSR, e mais tarde, o Moldavo SSR (Grenoble, 2003: 90).

Ignorar as razões políticas da identidade fundamental da língua standard dos dois lados do front seria uma idiotice que ninguém dotado de bom senso poderia aceitar, se não existisse esta ideia louca de denominar romena, esta língua teria como consequência automática a reivindicação de se unir à Romênia. O imbróglio discursivo é devido ao fato de que língua, nação e Estado são tratados como uma unidade "natural" (Bockmann 201: 32).

Os sites da $w e b$ de agências de viagens se dividem entre $-\mathrm{M}=\mathrm{R}$ e $\mathrm{M}$ é próximo de $\mathrm{R}$ :

"Nas ruas a língua romena ladeia a russa".

"A língua 'moldava' é somente outro modo de dizer "romena".

"O moldavo é uma língua muito próxima do romeno"

"O moldavo é bastante similar ao romeno."

A língua da Moldávia é o romeno. Muitas pessoas, quantificando a constituição chamam-na moldavense - esta é uma versão híbrida, levemente diferente do romeno. De acordo com os linguistas, o romeno e o moldavo referem-se à mesma língua.

(a") $\mathrm{M}=$ um dialeto de $\mathrm{R}$

O moldavo é basicamente um dialeto da língua romena. 
"MOLDAVO - Língua indo-europeia que é, de fato, uma forma dialetal do romeno [...].” (Caratini, 1992).

"Moldaviano, uma variedade paralela do Romeno." (Glyn Lewis, 1972: 264)

"Moldavo, aquele dialeto dos romenos falado lá." (Grenoble, 2003: 89)

(b) $\mathrm{M}=$

É preciso notar decididamente que este ponto de vista contradiz os próprios dados da língua moldava, o passado histórico do povo moldaviano e sua consciência linguística atual. Não há dúvidas de que as línguas romena e moldava são próximas, mas é, totalmente incontestável que os próprios moldavianos não consideram a língua romena como sua língua materna. Eles dão uma preferência evidente à língua que eles dominam de "limba moldovenjaskă”. (língua moldava) (Bernstejn 1950:10)

Uma justificativa corrente dos direitos da língua moldava à independência foi dada em trabalhos do Prof. Sergievskij. O estudo da história da língua moldava viva das regiões da margem esquerda do rio Dniestr conduziu o pesquisador soviético a afirmar a legitimidade da visão da língua moldava como língua independente, língua da nação moldava (Mixal'ci, 1953:56)

\section{LIMBA NOASTRA ROMÃNÃ}

CA!

\author{
EU SINT MOLDOVEAN! \\ EU VORBESC IN LIMBA MOLDOVENEAS-
}

Dois grafites contraditórios em RM. À esquerda: "Nossa Língua: o romeno” ’̀ direita: "Eu sou Moldavo! Eu falo moldavo!"

Mas para avançar em nossa reflexão sobre o estatuto científico da Linguística implicada em discussões sobre o nome da língua moldava é necessário lembrar alguns elementos indispensáveis ao conhecimento da situação local. Com efeito, para o ocidental mediano a Moldávia situa-se a pouca distância do "fim da terra," em um domínio que parece mais mal conhecido do que a Terra do Fogo. Edgard Quint (1856:16) fala da questão dos próprios romenos como: "os confins do mundo civilizado".

Quando a declaração da independência foi proclamada após a dissolução da União Soviética em agosto de 1991, a língua indicada como oficial foi a romena. Em 1994, entretanto, o artigo 13 da nova constituição estipulou que a língua de Estado era a Moldava. Finalmente, em 2013 o tratado constitucional retornou ao texto da Declaração da independência reconhecendo o romeno como a língua de Estado.

Mas esta decisão não foi introduzida na Constituição que mantém o moldavo como língua de Estado, ainda que a língua para o ensino escolar e universitário seja a romena, situação, por conseqüência, anti-constitucional.

É neste ponto que a questão terminológica adquire sua importância, para além daquela da tradução de termos empregados.

Faz-se uso, de modo incessante, na controvérsia, de dois termos difíceis de traduzir para a língua francesa. De um lado, rodnoj jazik não é a língua materna, mas uma espécie de língua da descendência ou do grupo étnico (rod corresponde ao genos do grego, gens do latim). Deste modo, nos censos, um cidadão moldavo que não fala senão o russo pode indicar o moldavo como sua "rodnoj jazik" declarando-se moldavo por etnia. De outro 
lado, a literaturnyj jazik que se pode traduzir por língua literária não é nem a língua da literatura nem a língua standard, mas a língua cultivada, oriunda de uma construção deliberada dos escritores a partir do material da "língua do povo" e que torna-se então, de acordo com os autores, ou a norma culta da "parte cultivada da população" ou a língua única do povo elevada ao estágio histórico da nação.

Exemplo: “(Na Moldávia) o trabalho de criação (sozdanie) de uma língua literária unificada, de enriquecimento e aperfeiçoamento de seus meios expressivos deu aos séculos xvii e xviii resultados significativos" (šismarev 1953:113).

Com certeza, este termo língua literária difere pouco do próprio sintagma empregado por Meillet, Tesniere ou mesmo Saussure ${ }^{11}$, no sentido de língua normativa, codificada (conforme o alemão hochsprache). Mas na ideologia romântica que caracteriza o discurso sobre a língua na Europa oriental, esta língua literária repousa sobre o pressuposto de "unanimidade do povo todo", provocando, deste modo, confusões incessantes entre a norma e o uso. A língua, como a nação, é suposta como um dado objetivo, mas ao mesmo tempo ela está por ser construída. Passa-se assim, sem cessar, da descrição à injunção do ser ao dever ser:

A nova situação proporcionou novos direitos à Moldávia, mas lhe impôs também novas obrigações, entre as quais se encontram a elaboração e o aperfeiçoamento da língua nacional como instrumento da literatura, da ciência e de outros aspectos do trabalho ideológico e cultural (Šismarev 1953:115)

A língua literária é de uma vez um fato acabado pelos grandes escritores próximos do povo, após muito tempo, e uma tarefa a perseguir de modo indefinido em uma abordagem histórico-cultural fortemente distante de uma perspectiva saussuriana, ou uma dialética embrulhada apoiando-se sobre o procedimento retórico " a entretanto não-a”, reunindo posições incompatíveis. Deste modo, R. Budagov, à propósito da "intervenção consciente na língua" escreve:

Há muito tempo que a tradição do pensamento lingüístico russo recusa a oposição entre noções como “ objetivo" e sujeito à intervenção". A língua evolui de modo perfeitamente objetivo em condições independentes dos homens, não obstante os homens falem a língua em questão e em primeiro lugar os escritores e cientistas eminentes sejam capazes de agir [vozdejstvovat] sobre a língua, sobre suas especificidades lexicais, semânticas, sintáticas e estilísticas (Budagov 1976: 6)

11 Ver Saussure "Curso de Linguística Geral”, p.267,68 “ a unidade lingüística pode ser destruída quando um idioma nacional sofre a influência de uma língua literária. Isto se produz infalivelmente toda vez que um povo atinge um certo grau de civilização. Por "língua literária” entendemos não somente a língua da literatura, mas em um sentido mais amplo toda espécie de língua cultivada ou não, oficial ou não, a serviço de toda a comunidade. Entregue a si mesma a língua não conhece senão os dialetos, dos quais nenhum é usado nos outros e por isso está condenada a um fracionamento indefinido. Mas como a civilização, ao desenvolver-se, multiplica as comunicações, escolhe-se, por uma espécie de convenção tácita, um dos dialetos existentes para torná-lo o veículo de tudo que interessa à nação em seu conjunto.

Esta noção de "língua literária" na obra de Saussure não tem, portanto, muita coisa a ver com seu conceito de "língua" como "um conjunto onde está tudo" e onde os elementos são definidos negativamente:"Sua característica exata é de ser o que os outros não são" (ibid., p.162. 
A língua literária moldava possui suas particularidades em relação à norma literária e ao uso dos escritores contemporâneos moldavos. Há vinte anos o acadêmico V. Šismarev notou com razão: "O trabalho de desenvolvimento e de aperfeiçoamento da língua na Moldávia é atribuição dos círculos cultos do próprio povo moldaviano e em primeiro lugar de seus escritores" (ibid.,p.7)

Uma leitura atenta destes textos proibitivos permite trazer à luz um certo número de pressupostos ou postulados da base da controvérsia. O objeto de discurso é de natureza essencialmente ontológica; nenhuma dúvida sobre sua construção vem perturbar a ladainha lancinantes de declarações e inventivas, oscilando entre encontrar e reivindicar, onde a linguística desempenha um papel predominante. Deste modo, o primeiro princípio é que as etnias existem, fenômenos objetivos enumeráveis, identificáveis por uma língua particular, perfeitamente distinta de outras línguas. É bom porque o desafio, nestas versões rivais de discurso identitário, de denominação da língua falada pela maioria dos cidadãos moldavos é fundamental: trata-se dos moldavos, eles constituem uma nação diferente da Romênia, então a anexação da moldávia à Romênia seria privada de sentidos. Em revanche, trata-se do romeno, a Moldávia constitui uma terra irridente, artificialmente separada da mãe-pátria romena. Mas o círculo é vicioso pela inversão da prova, em um silogismo que gira em círculos:

(1) A Moldávia é uma nação

Mas toda nação se define por sua língua

Logo, a Moldávia é constituída por sua língua moldava

(2) O moldavo é diferente do romeno

Mas na Moldávia se fala o moldavo

Logo a Moldávia é uma nação.

Pode-se multiplicar assim os paralogismos, cujo maior ou o menor coloca já no início o que se pretende demonstrar:

(1) Tantas nações, tantas línguas nacionais

Mas a Moldávia é uma nação

Então o moldavo é a língua da nação moldaviana.

(2) Aqui está o maior que é o elo mais fraco

O moldavo é uma língua em si mesma

Mas como muitas nações, tantas línguas nacionais

Portanto a Moldávia é uma nação de pleno direito.

Nesta ontologia surpreendente onde falar moldavo significa ser moldavo ${ }^{12}$, como no paradoxo do ovo ou a galinha, só constituem uma mesma essência inextricável, insubmissa a qualquer análise racional. Assim, todo o edifício, simultaneamente positivista e romântico, da equação "uma língua = um povo = uma nação" é uma construção instável, um ser de papel.

12 Conforme o título do artigo de Vicu-Poustovaia (1996) "Se sou moldaviano, falo moldavo" ou " falo romeno, portanto sou romeno". 
No máximo, o moldavo pode ser considerado pela maioria dos sociolinguistas como uma língua Abstand (moldada pelo uso local), variante do romeno, o qual é uma língua Ausbau, "erudita", denominada "literária", na ex-URSS, dentre as diferentes variantes de línguas românicas orientais. Mas esse moldavo oficial, padronizado, não deve ser confundido com o falar corrente, regional, comum na Bessarábia $e$ na Moldávia romena. Por sua vez, esse falar regional pode ser diferenciado em duas sub variantes dos dois lados da fronteira do rio Prut.

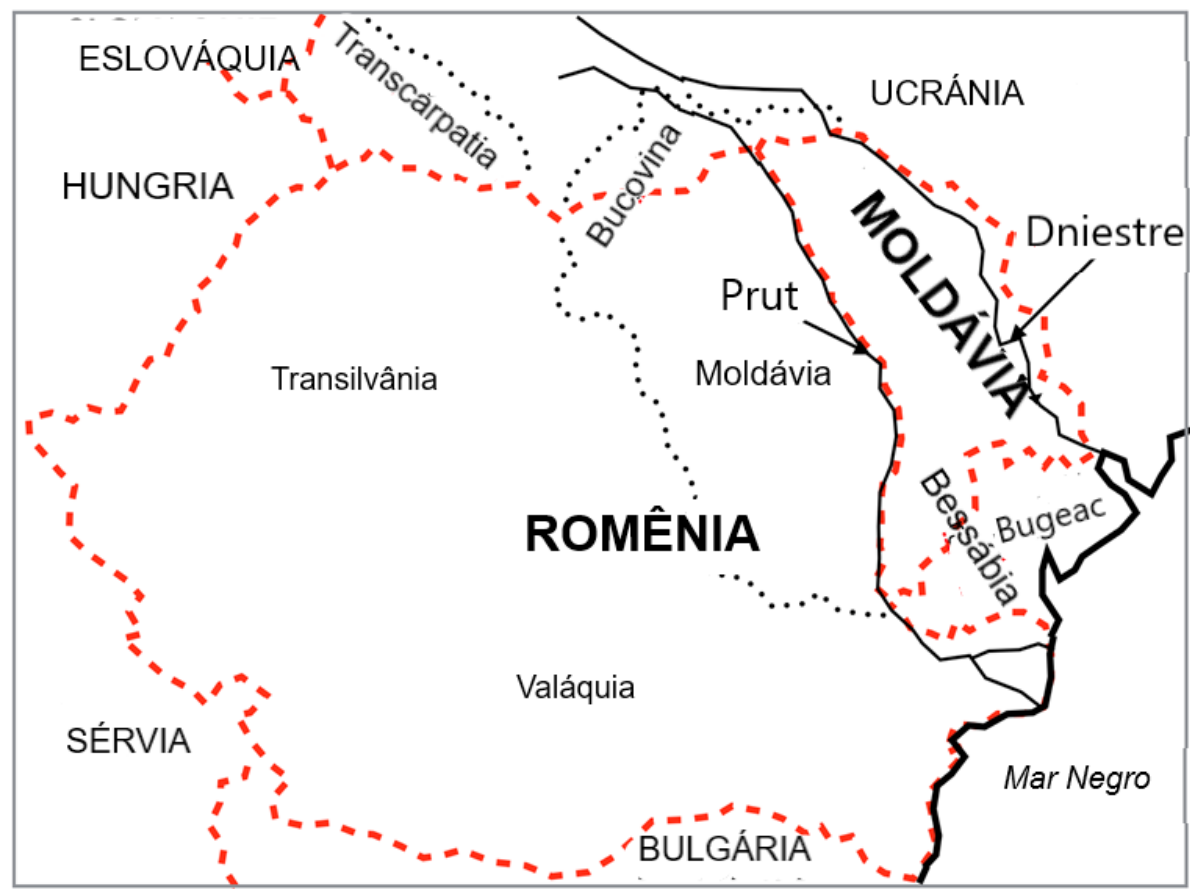

\section{(O discurso sobre) os fatos (confusos)}

Vamos tentar resumir sucintamente a marcha dos fatos, difíceis de desenredar da rede inextricável dos discursos históricos nacionalistas mutuamente incompatíveis.

Vamos iniciar com os fatos, se é que podemos falar de fatos quando se trata de signos, pois é a ordem do discurso que está aqui questionada. O discurso sobre a língua é uma cripto política, uma política que, sob o pretexto de nominação de um objeto supostamente preexistente, não ousa dizer seu nome. Nas ciências humanas e sociais, os nomes são armadilhas, e seu referente é móvel.

Existem duas Moldávias, e uma delas, por sua vez, dividida em duas. Mas nenhuma das três corresponde à Moldávia histórica.

Entre a ocupação romana da Dácia (de 106 à 270) e a fundação, no século 14, dos dois "principados danubianos", o da Valáquia e o da Moldávia, localizados entre o arco da cordilheira dos Cárpatos e o rio Dniestr, se situam os obscuros séculos cuja história é tão mal 
documentada, que propicia interpretações contraditórias. A tese romena nacionalista é autoctonista: há continuidade da população romena na Romênia desde o período romano. A tese húngara e (talvez) russa é migracionista: Os Romenos vieram do sul do Danúbio e não descendem de colonos romanos. Em ambos os casos, a verdade se impõe por si mesma e dispensa argumentos. ${ }^{13}$ Essas duas teses têm em comum a reivindicação da primazia da ocupação de um território, esquema universal de disputas nos Balcãs; se os Dácios são espécies dos Eslavos, então esses últimos são um povo autóctone, e os Romenos invasores tardios. O conflito se agrava com acusações recíproca de "barbárie" 14 .

Em pouco tempo, os principados são vassalos do Império Otomano. A composição étnica é uma enorme diversidade. A religião, trazida pelos Búlgaros, é ortodoxa (sobre a língua escrita ou "língua literária", v. seção seguinte). Essa região é de uma importância estratégica capital: é via de acesso para a Rússia aos estreitos que permitem a passagem ao Mar Negro. Após as guerras entre Rússia e Turquia ${ }^{15}$, uma metade da Moldávia, a Bessarábia, localizada entre os rios Prut e Dniestr, é anexada pela Rússia pelo Tratado de Bucareste, em 1812. O hospodar (dirigente) moldávio protesta, pois o tratado de vassalagem moldávio-otomano previa a intangibilidade das fronteiras da Moldávia, mas prevaleceu a força das armas.

Após um curto período de tolerância, a língua local foi eliminada de todas as funções oficiais e somente o russo tornou-se a língua administrativa e de ensino ${ }^{16}$. No final do século 19 não havia um único livro na língua moldávia na biblioteca pública de Kišinev/ Chişinău (Šišmarev 1953 : 114). No entanto, os Alemães, Búlgaros e Gregos ${ }^{17}$ conservaram o direito de estudar suas próprias línguas no ensino público.

Conforme os pontos de vista, após a anexação/incorporação ${ }^{18}$ de 1812 , os habitantes da Moldávia Ocidental (margem direita do Prut) se refugiaram na Bessarábia para fugir da ordem otomana, ou, ao contrário, os habitantes da Bessarábia passam para o lado ocidental para reencontrar sua verdadeira pátria. A partir de 1878 a fronteira do Prut é fechada hermeticamente no lado russo. Também ali, os discursos identitários nacionalistas são incompatíveis. Os romenófilos ressaltam a opressão czarista na Bessarábia (a servidão foi-lhes imposta, ao passo que ela fora abolida nos Principados desde 1774); os russófilos, ao contrário, insistem no aspecto positivo e civilizador do pertencimento à Rússia:

A anexação [prisoedinenie] da Bessarábia pela Rússia desempenhou um papel positivo: auxiliou a separar a Moldávia de antigas tradições semi-orientais e favoreceu o contato do povo moldavo com a cultura russa, mais elevada. [...] A separação da Bessarábia da Moldávia ${ }^{19}$ teve por consequência o abandono das tradições orientais atrasadas que frea-

13 Exemplo : “isso não faz sombra de dúvida, a presença contínua do elemento romeno na margem esquerda do Danúbio é uma verdade autoevidente". (Bogdan 1905 : 17, citado por Šišmarev 1952 : 81).

14 Sobre o tema da "barbárie dos Romanos", vide. Sériot 1988.

15 O czar da Rússia era o "protetor" dos cristãos ortodoxos do Império Otomano, como o Imperador Napoleão III era o dos cristãos católicos.

16 Do mesmo modo, na Bucovina, anexada pelos Austríacos na mesma época, outro protetorado do Principado da Moldávia, é o alemão que se torna a língua oficial.

17 Fique bem claro que se tratam de sujeitos do Império Russo falantes do Alemão, do Búlgaro e do Grego, e não cidadãos estrangeiros.

18 Nesse artigo, as expressões do tipo "anexação/vinculação" ou "ocupação/libertação" de determinado território são deixadas ao julgamento do leitor, que poderá excluir as menções inúteis em função de suas convicções ou de seu senso de objetividade.

19 No século xix, para os Russos, a Bessarábia (margem esquerda do rio Prut) estava em oposição à Moldávia (margem direita). 
ram o desenvolvimento da Moldávia como dos outros países balcânicos, onde a Rússia desempenhou um papel objetivamente progressista. Foi na Rússia czarista, não obstante o jugo e o obscurantismo do czarismo, que se desenvolveram o pensamento progressista e o movimento revolucionário, aos quais, pouco a pouco, se juntou a Bessarábia

(Šišmarev $1953: 115)$

Em 1859, a Valáquia e a Moldávia ocidental se reuniram para constituir a “(pequena) Romênia", liberta dos Turcos, o alfabeto latino é adotado, enquanto na Bessarábia (Moldávia oriental) permanece o uso do alfabeto cirílico em sua versão precisamente russa.

Criadas pelo movimento nacional romântico, as elites romenas se esforçam em "romanizar novamente" a língua moldo-valáquia, recentemente unificada sob o nome de romeno, com a introdução de numerosos neologismos formados a partir do Latim, do Italiano e do Francês, almejando converter o Romeno no "francês do Leste" (v. Kamusella 2015 : 41).

Ao fim da Primeira Guerra Mundial, a Bessarábia é "ocupada / libertada” pela Romênia, que recebe esse território pelo Tratado de Saint-Germain, de 1919, para formar, com a Transilvânia e a Bucovina, a Grande Romênia. A língua oficial do território da Bessarábia passa a ser o Romeno da Romênia. Mas o clero ortodoxo protesta contra a introdução da escrita latina, já que o alfabeto cirílico havia sido até então utilizado pela Igreja (ortodoxa) na Bessarábia e os pais dos alunos relutavam em passar do Russo ao Romeno de alfabeto latino (conforme Martone, 1919 : 524).

O Reino da Grande Romênia (1919-1944) é um período considerado pelos círculos moldavos romenófilos uma espécie de era de ouro de sua nacionalidade, ao passo que para os soviéticos trata-se, pelo contrário, uma ocupação estrangeira "burguesa" da Bessarábia.

Durante o período de 1945-1989, a República Socialista Soviética da Moldávia (RSSM) está separada da Romênia, mesmo sendo ambas socialistas, por uma fronteira completamente fechada. Os arames farpados na margem soviética do rio Prut impedem o acesso e a pesca (ao passo que no lado romeno o acesso ao rio é livre). Os contatos com a Romênia são reduzidos ao mínimo e os livros romenos são mais facilmente acessíveis em Moscou que na capital moldava Kišinev/Chişinău.

Desde os acontecimentos de 1812, a dança das denominações causa vertigens. A partir daquele momento, o significante Moldávia remete ao todo ou a uma das duas partes, em uma ronda incessante mais raramente explicitada.

$\mathrm{O}$ adjetivo geográfico moldavo se refere a tudo o que interessa ao território histórico da Moldávia. Quanto ao gentílico "moldávio", ele pode designar os habitantes da Moldávia histórica (aquela de antes da separação de 1812), às vezes somente aqueles da República da Moldávia, outras vezes somente os falantes do moldávio dessa última.

$\mathrm{O}$ antigo Principado da Moldávia atualmente está dividido entre:

- a região da Moldávia na Romênia, a oeste do rio Prut;

- a República da Moldávia (nome oficial: Moldova) a leste do Prut, sucessora da República Socialista Soviética Moldávia,

- e Ucrânia, ou seja o oblast (subdivisão territorial em alguns países eslavos e ex-repúblicas soviéticas) de Tchernivtsi (ou Cernăuți, em romeno), e a parcela do oblast de Odessa situada a oeste do Nistru ou Dniestre (Bugeac).

Os dois últimos territórios foram criados por Stalin depois da anexação/reanexação/ reocupação/recuperação/libertação da Bessarábia soviética,em junho de 1940, permitida pelo Pacto de Não Agressão Germano-Soviético, de 1939. 


\section{Moldávia romena}

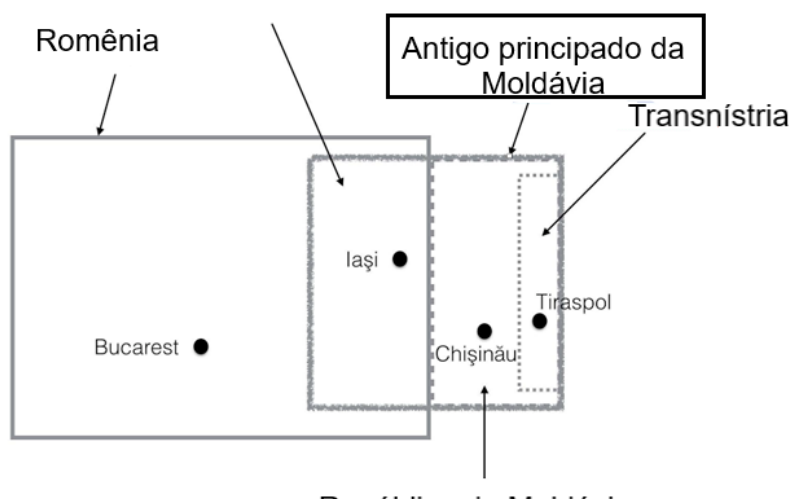

República da Moldávia

Qual língua era falada? Onde e quando?

Durante muito tempo, a língua escrita na Valáquia e na Moldávia foi o eslavo da Igreja (a religião dominante era a ortodoxa, trazida pelos Búlgaros e não pelos Gregos, em estreita relação com a Igreja da Rússia). Os primeiros textos escritos em língua vernacular (1643) são no alfabeto cirílico. Essa língua vernacular é conhecida no século xix, no Ocidente, sob o nome de moldo-valáquio.. O adjetivo moldo-valáquio há muito tempo tem em francês o sentido pejorativo de "país distante e bizarro, talvez inexistente" (Dicionário Larrouse, s.d.), e de língua incompreensível, papo furado, charabiá. ${ }^{20}$ Tratava-se de uma língua de base latina mas contendo numerosos elementos eslavos. Segundos as versões, o moldo-valáquio era uma língua unitária (tese romena) ou, ao contrário, o moldávio e o valáquio eram duas línguas diferentes (tese soviética). A partir dessa diferença de julgamento podem ser estabelecidos dois discursos concorrentes: o romeno da Romênia é talvez o resultado da simbiose entre o romeno e o valáquio, ou ao contrário, a normalização do valáquio em detrimento do moldávio.

Em 1860, a língua oficial da Romênia, sob o nome de Romeno (limba româna) adota o alfabeto latino. A "relatinização" do vocabulário empreendida pelos eruditos romenos teve por objetivo reencontrar a "natureza verdadeira" da língua romena. Ali, novamente, duas posições se confrontam nessa construção identitária: seja uma aspiração para reencontrar as raízes autênticas mas esquecidas; ou, de forma contrária, uma desculturação da autêntica língua moldávia, privada de seus numerosos empréstimos eslavos, portanto não ocidentais.

\section{O moldavo na RASSM}

Em 1924, no território ucraniano soviético, foi criada a República Autônoma Soviética Socialista Moldava (RASSM), que corresponde mais ou menos à atual Transnístria, uma es-

20 A Sildávia explorada por Tin-tin tinha sido inventada por seu desenhista Hergé no fim dos anos 1930, como aproximação da Transilvânia e da Moldávia. 
pécie de cabeça-de-ponte para reivindicar o pertencimento da Bessarábia à URSS. Esse território, situado na margem esquerda do Dniestr nunca tinha feito parte da Romênia, nem do principado de Moldavia, e sua população era composta majoritariamente de ucraniófonos.

O pacto germano-soviético (1939) autorizou a URSS a ocupar/anexar/libertar a Bessarábia em 1940. Alguns meses mais tarde, a Romênia, então aliada da Alemanha, ocupou/libertou novamente a Bessarábia, de onde ela foi definitivamente expulsa em 1944 pelos Soviéticos.

Já em 1924, na RASSM recém-criada, estava-se discutindo a constituição de uma língua moldava que fosse a mais diferente possível do romeno. Partindo do princípio de que a língua é conteúdo e que o romeno era uma "língua burguesa", as primeiras decisões foram no sentido de constituir uma "língua autêntica do povo": o moldavo. Aparece aqui a ambiguidade da palavra "povo" [narod], que, num sentido socialista, opõe-se à aristocracia e à burguesia e, no sentido romântico, opõe-se como um todo aos outros povos e, nesse caso, ao povo romeno.

Em um primeiro período, de 1924 a 1926, as normas romenas foram aceitas. A seguir, de 1926 a 1936, os quadros comunistas bessarabianos exilados na RASSM pregaram uma política de criação de uma norma que fosse a mais afastada possível do romeno.

No seu prefácio à gramática moldava de Madan, publicada na RASSM en 1929, o Comissário do povo para a Instrução, P. Chior (1902-1943) criticava as primeiras tentativas de normatização do moldavo em território soviético (1925):

No que diz respeito às formas de desenvolvimento da língua, sua orientação, seu léxico e, sobretudo, sua ortografia, dominava nos estabelecimentos culturais centrais da República, uma orientação 'pseudomoldava', isto é, romena. [...] Para alguns, essa orientação incorreta (romena) era baseada em uma acepção mecânica, acrítica, da língua moldava tradicional, deixada por nacionalistas-romenófilos da Bessarábia e também pela Igreja bessarabiana, na sua propaganda a respeito da língua 'panromena'. Para outros, havia o medo das dificuldades em desenvolver e dar forma à 'pobre' língua moldava, enquanto existia uma língua romena 'rica, desenvolvida e já padronizada'. É claro que essas duas orientações estavam erradas sob todos os pontos de vista, inclusive político. A orientação romena na língua, naquela época, estava em total contradição com a língua popular viva moldava, que não se enquadrava com nenhum quadro artificial romeno. [...] Para as grandes massas moldavas, a língua e a ortografia de 1925 eram incompreensíveis, inadmissíveis e disso são testemunhas as muitas intervenções dos operários, camponeses e representantes da intelligentsia de base na ocasião dos congressos dos Soviets, dos correspondentes no campo [sel'kory], das conferências de professores, etc. Foi somente no outono de 1926 que os órgãos dirigentes, entre eles o comissário do povo para a instrução da RASSM, enfrentaram a questão da língua, de seu desenvolvimento, sua orientação, sua ortografia, etc. As decisões do Plenum de outubro do PC(b) da Ucrânia e do segundo Congresso dos Sovietes da RASSM trouxeram uma clareza definitiva nas discussões acirradas em torno da língua moldava. Essas decisões estabeleceram claramente a necessidade de desenvolver e padronizar [oformlenija] a língua moldava; que a língua moldava era de fato uma língua à parte, diferente do romeno, o qual, mesmo sendo efetivamente aparentado ao moldavo, não deixava de ser, em razão de diversas circunstâncias históricas, estrangeiro e incompreensível para os moldavos. (Chior 1929: III-V)

Mas essa orientação puramente moldocêntrica é rapidamente rejeitada em nome da "luta contra o nacionalismo local e o chauvinismo de grande potência", tornada dogma no 
$16^{\circ}$ Congresso do PC(b), em 1930. Em 1932, na RASSM o alfabeto latino é introduzido por decisão do Comitê Executivo da Ucrânia e da RASSM, e normas mais próximas do romeno da Romênia são recomendadas:

Até o início de 1932 a língua literária moldava tinha sido submetida à numerosas distorções. O grupo de 'autoctonistas' [samobytniki], que se instalou firmemente no Comitê Científico, tentou implementar a teoria de Skrypnyk sobre 'as duas línguas e as duas nacionalidades se encontram de um lado e de outro do Dniestr'. Esse grupo se esforçou para construir uma língua literária moldava exclusivamente a partir do dialeto local, transformando-a dessa forma numa língua incompreensível para os moldávios falantes de outros dialetos. Um certo Madan, que era na época presidente da seção linguística do Comitê Científico, havia inventado e introduzido na língua literária palavras incompreensíveis para as massas trabalhadoras moldavas.

A organização moldaviana do Partido combateu o "autoctonismo" e o "madanismo" e seguiu uma linha clara de aperfeiçoamento e embelezamento da língua literária para torná-la compreensível a todos os Moldavos, não importando onde habitassem ou qual seu dialeto. Ao mesmo tempo, uma luta foi levada a efeito contra as tentativas de passar na literatura ${ }^{21}$ moldava o léxico afrancesado da classe dirigente da Romênia, totalmente incompreensível aos Moldavos, mesmo na Romênia. Mas isto não quer de forma alguma dizer que não foi necessário introduzir na língua literária da Moldávia soviética as riquezas da língua literária das belas-letras ${ }^{22}$ romenas. A língua literária moldava, na sua luta impiedosa contra o chauvinismo do grande poder e o nacionalismo local, em conluio com o nacionalismo ucraniano e os intervencionismos imperialistas, irá ascender a um estágio superior. (Grande $1936: 177)^{23}$

Por sua vez, essa política de retorno às normas panromenas é atropelada quando dos expurgos de 1936-37, com a chegada ao poder de novos quadros, autóctones da margem esquerda do Dniestr, descendentes russificados dos Moldavos que tinham fugido da tutela turca no século XVIII. O alfabeto cirílico é reintroduzido, e se estabelece uma norma mais próxima do russo, em nome da luta contra o nacionalismo "burguês" e da aproximação com as massas proletárias russas. A língua literária é, assim, uma massa maleável, submetida aos riscos políticos do momento, mas sempre em nome da "compreensão pelo povo", aquilo que os detratores do regime soviético chamam "transformação de sua língua em um jargão Moldavo-Russo-Ucraniano” (Bruchis 1982).

No momento da criação da RASSM em 1924, ainda não existia uma gramática propriamente dita do moldavo. De acordo com o princípio romântico-estaliniano de que uma nação é, entre outras coisas, uma única língua, o Politburo do Partido Comunista da Ucrânia lançou uma campanha de criação de uma língua moldava, manifestação intrínseca de uma nação moldava. Era preciso proceder de maneira sutil nessa confusão entre a causa e a consequência, entre o ser e o dever-ser, no impasse formado pelo oximoro descrição/ prescrição: uma nação é uma nação porque ela possui uma língua, mas para que ela seja uma nação, é preciso inventar-lhe uma língua. A língua moldava existe, mas, ao mesmo tempo, é preciso construí-la.

21 "Literatura" aqui não designa unicamente as belas-letras, como no francês, mas o conjunto da produção escrita : científica, técnica, política, etc.

22 Aqui, ao contrário, trata-se de "literatura x" no sentido francês tradicional (xudožestvennaja literatura).

23 Idem. 
Duas posições se opõem: um discurso naturalista, para o qual a especificidade da língua moldava deve ser averiguada, e um discurso voluntarista, segundo o qual essa especificidade deve ser construída. É preciso, portanto, criar uma gramática normativa do moldavo, na base de "falares vivos" na margem esquerda do Dniestr, mas, ao mesmo tempo, afirmar que a língua moldava existe desde os primeiros escritos do Principado da Moldávia, no século XVII. Nesse caso, a língua moldava seria idêntica dos dois lados do Prut. Mas, nesse caso, como se justificaria a fronteira com a Moldávia romêna? Haveria um só povo e duas nações?

Ainda assim, o problema da instauração da RASSM apresentava uma dupla limitação: era preciso construir uma identidade nacional (anti-romena) e, ao mesmo tempo, combater o etnonacionalismo inerente a essa mesma construção, em nome do internacionalismo proletário. Essa insustentável contradição estava na base da extrema tensão da glotopolítica soviética na época staliniana.

Em 1925 a ortografia cirílica foi oficializada e as inovações linguageiras foram estabelecidas. G. Bučuškanu, comissário do povo para a instrução pública da RASSM, publicou uma gramática, mas com a ortografia cirílica utilizada na Bessarábia antes da revolução de 1917 (embora seu uso tivesse sido proibido desde 1848) (v. Chior 1929: III).

O projeto geral revela uma inspiração que hoje chamaríamos de "populista": tratava-se de criar uma "língua literária" próxima do povo, eliminando todos os empréstimos e forjando palavras supostamente passíveis de serem diretamente entendidas pelo povo. Um tal abordagem da língua não tinha nada de original, já que seguia inteiramente a política linguística dos nacionalistas românticos da Europa Central do início do século XIX, especialmente os tchecos. ${ }^{24}$ A gramática de Madan (1929) afirmava seguir os "princípios marxistas-leninistas de abordagem da questão linguística”. O produto dessa atividade de fabricação da língua, chamado "jargão híbrido moldo-russo artificial” por seus detratores estrangeiros (Deletant 1990 : 195 ; Bruchis 1996 : 22), seguiu os princípios do linguista moscovita M. Sergievskij, que em 1939 cobriu de louvores essa gramática de Madan, porque tinha livrado a língua moldava de seus elementos estrangeiros de maneira a torná-la a língua do povo moldávio e não mais aquela dos proprietários de terras romenos (vistos como boiardos: senhores feudais da aristocracia russa). Aqui a língua pode apenas refletir a ideologia de uma classe social.

Por exemplo, para a palavra ortografia, optou-se por traduzir literalmente a palavra grega, resultando dreapta scriere ["escrita direita"], uma vez que a palavra emprestada ortografia já fazia parte do romeno. Bem como hidrogênio tornou-se generator de apă [gerador de água"] para se distinguir do romeno hydrogen. Esses inumeráveis neologismos se inscreveriam no ar do tempo: na mesma época o populismo linguístico transformou, na Alemanha, Telephon [telefone] em Fernsprecher [falante à distância], que,

24 Nos anos 1820-30 os intelectuais tchecos lançam a ideia do "despertar nacional" (národní obrozeni) :. Sendo eles todos germanófonos não se conformavam com o fato de que a vida pública e cultural estivesse nas mãos dos mestres austríacos. Mas o tcheco era, naquela época, a língua dos camponeses e dos trabalhadores domésticos.. Eles inventaram então neologismos sobre uma base inteiramente autóctone. Dessa forma, Geografia torna-se zemlěpis, tradução literal do grego « terra-escrita". Mas resta compreender porque tais inovações foram recebidas, em terras tchecas, com entusiasmo, ao passo que na Moldávia elas somente suscitaram incompreensão e repressão. Observemos que no início da guerra da Iuguslávia, por volta de 1991, os nacionalistas croatas propunham substituir televizija por dalekovidnica, tradução literal do grego "longe-ver". Mas o que deveria ter sido, supostamente, uma palavra autêntica da língua do povo, era, na verdade, apenas um decalque da palavra alemã Fernsehen... 
supostamente, melhor correspondia ao espírito da "língua nacional". Mas na RASSM a criação da "língua do povo" pelos intelectuais, expressão ambígua emergente tanto da ideologia romântica como do socialismo, apresentou dois inconvenientes fundamentais. De um lado, depois de numerosos testemunhos, a maior parte dos "neologismos populares" eram, realmente, "eruditos", portanto incompreensíveis para aqueles a quem eles eram destinados. Mas, ainda pior, eles excluíam as palavras internacionais do russo e do ucraniano. Ora, a glotopolítica na RASSM era, além disso, dilacerada entre duas tendências políticas contraditórias. De um lado, o projeto (implícito) de expansão do socialismo na totalidade do território romeno precisava reforçar as normas do romeno em grafia latina. De outro, era necessário opor-se a qualquer veleidade nacional panromena dos romenofones da margem esquerda do Dniestr, bem como da Bessarábia “anexada/ocupada/ vinculada" pela Romênia, criando, então, assim uma língua tão diferente quanto possível do romeno (apesar dos protestos dos comunistas romenos não-stalinistas).

A gramática de Madan (1929) afirma seguir os "princípios marxistas-leninistas de abordagem da questão linguística". O produto dessa atividade de fabricação da língua, chamado "jargão híbrido moldo-russo artificial" por seus detratores estrangeiros (Deletant 1990 : 195 ; Bruchis 1996 : 22), seguiu os princípios do linguista moscovita M. Sergievskij, que em 1939 cobriu de louvores essa gramática de Madan, porque tinha livrado a língua moldava de seus elementos estrangeiros de maneira a torná-la a língua do povo moldávio e não mais aquela dos proprietários de terras romenos (vistos como boiardos: senhores feudais da aristocracia russa). Aqui a língua pode apenas refletir a ideologia de uma classe social.

Tais orientações geopolíticas e, portanto, glotopolíticas contraditórias traduziram-se por mudanças bruscas na gestão da questão da língua na RASSM. Deste modo, a introdução do alfabeto cirílico na RASSM em 1924 (em contradição com a primeiro ato visível de diferenciação com o romeno e de aproximação com o russo. Mas após um período de franca hostilidade, em 1933, a URSS e a Romênia, diante da ameaça comum alemã, retomam os contatos diplomáticos.

O alfabeto latino, com suas normas romenas, foi reintroduzido na Romênia e neologismos romenos foram adotados, o que significava um reconhecimento tácito da identidade do moldavo e do romeno. Os linguistas que haviam forjado a nova língua moldava a partir de provincialismos e neologismos foram acusados de nacionalismo e destituídos. Mais especificamente, a gramática de Madan (1929) foi acusada de criar palavras "artificiais" que tornavam a língua moldava confusa e petrificada (Diaconescu 1942:218, apud Deletant 1990:193). Essa surpreendente orientação proromena só durou 5 anos. Em 1938, o cirílico foi novamente oficializado. Dessa vez, a gramática de Madan foi novamente criticada, mas por razões opostas: as de "se opor à amizade e à cooperação entre o povo moldávio e os povos russo e ucraniano" (ib.) Os linguistas e gramáticos promotores de tal política de abertura, acusados de "romanização" da língua moldava, hostil ao povo, foram também destituídos de seus cargos, encarcerados e, em alguns casos, fuzilados. Os sobreviventes foram encarregados de liberar a língua moldava de seus "elementos estrangeiros", isto é, dos vocábulos romenos tomados emprestados do francês, ininteligíveis para o povo moldavo, introduzidos pelos inimigos do povo, e deviam forjar novas palavras, ligadas à construção do socialismo, a partir do russo e do ucraniano, línguas dos povos irmãos ${ }^{25}$.

25 Prefácio do Cuvintelnic ortografic moldovenesc [Dicionário ortográfico moldavo],Tiraspol,1939, apud Bruchis, 1982:61. 
O discurso sobre a língua na URSS na época estaliniana era marcado por uma dupla condicionante, que desestabilizava qualquer tentativa de gestão racional da questão da língua, além de colocar em perigo qualquer tentativa por parte dos linguistas profissionais, chamados mesmo assim a aplicar a "política nacional" do Partido ${ }^{26}$. Era preciso implantar uma identidade moldava (anti romena), sem permitir que ela se afirmasse demasiadamente como anti russa.

Desse modo, os "puristas romenos" foram ao mesmo tempo acusados de cosmopolitismo:

Nos anos 1920-30, seja em função das novidades utópicas ou dos objetivos hostis dos nacionalistas burgueses, que queriam inventar uma língua e uma terminologia novas e criar uma nova ortografia sem nenhum outro fundamento que não fosse a tendência nefasta do proletkult marrista, ou ainda em função dos objetivos cosmopolitas, estranhos para nós, dos nacionalistas burgueses romenos, querendo impor à língua moldava a ortografia das línguas da Europa ocidental, com vestes latinas, pudemos observar frequentes mudanças de sistemas ortográficos do moldavo, sem nenhuma utilidade para quem que fosse. (Ceban 1951: 17-18)

Ao forjar inúmeros termos artificiais [nadumannyx], deformar a ortografia e manchar a língua com palavras pouco usadas, locais ou arcaicas, nos anos 1920, os nacionalistas burgueses locais procuraram semear a confusão na língua. Nos anos 1930, os nacionalistas burgueses, ao apoiar a política dos proprietários de terras romenos, ao introduzir, sem necessidade alguma, o alfabeto latim, palavras e expressões eruditas vindas da Europa ocidental, vocábulos e termos estrangeiros, ao contrapor a ortografia à pronúncia do inteiro povo, aplicaram-se a sobrecarregar a língua de termos incompreensíveis. Contudo, todas essas iniciativas marristas e proletkultistas foram vãs, pois o povo não as apoiou. Todas essas inovações macularam a língua, mas não sendo numerosas, elas não chegaram a atingir o essencial, isto é, a estrutura gramatical e o fundo lexical de base, que se mantiveram imutáveis. (ib.: 11-12)

Essas diatribas, que se reivindicavam do marxismo, apoiavam-se, apesar das denegações, em uma retórica naturalista, na qual a língua moldava seria dotada de capacidades de resistência:

O registro fotográfico naturalista da ortografia do moldavo, pelos nacionalistas locais e as 'novidades' fônicas dos nacionalistas burgueses romenos afetaram apenas superficialmente o léxico [slovarnyj sostav], que não constitui a base da língua e que 'se encontra em um estado de transformação quasi constante'(Stalin, 1950: 11). (Ceban 1951:18)

\section{$\mathrm{O}$ alfabeto}

É necessário tratar a questão do alfabeto, ou, mais exatamente, da base gráfica da língua moldava.

A "tese" adotada, em novembro de 1988, pelo Comitê Central do PC moldavo, pelo Presidium do Soviet supremo e pelo Conselho dos ministros da república estipulava que “o moldavo e o romeno são línguas do mesmo grupo românico; [...] existe uma tradição

26 Aqui "política nacional" está para gestão das "nacionalidades" no sentido étnico e não de cidadania.

52 - Conexão Letras, Porto Alegre, v. 14, n. 22, p. 37-67, jul-dez. 2019. 
nacional de utilização do alfabeto cirílico, [...] o qual corresponde perfeitamente à especificidade fonética da língua moldava", o que suscitou a indignação da parte romenófila da intelligentsia nacional, assim como de inúmeros cidadãos.

Nos anos 1988-89, a Frente popular moldava e a União dos escritores reivindicaram a extensão das funções sociais do romeno assim como a passagem do cirílico ao alfabeto latim, por esse ser "mais adaptado a uma língua românica” (Bruchis 1996:34) 27.

O tema geral era portanto a "melhor adaptação" de um alfabeto a uma língua. Isto é, mais uma vez, o argumento consistia em uma afirmação tonitruante e inapelável.

O linguista A. Boršč, ex-chefe do departamento de moldavo na universidade de Chišinaŭ, pôde assim escrever: a) "os moldavos utilizaram o alfabeto cirílico sem interrupção até hoje", b) "o alfabeto cirílico pode transcrever, com a maior precisão possível toda a riqueza da língua moldava e a especificidade de seu sistema fonético." (in Narodnoe obrazovanie [A educação popular], Chišinaŭ, 13/08/88, apud Bruchis 1996 : 36).

Em agosto de 1989, enquanto o princípio de uma distinção linguística entre o moldavo e o romeno começar a ser abertamente criticado, o primeiro secretário do PC moldavo, $\mathrm{S}$. Grossu, afirmava ainda que as duas línguas eram totalmente distintas e que o alfabeto latim era "inapto a retranscrever a língua falada".

Sob pena de ser politicamente incorreto, considero pertinente afirmar que o cirílico pode perfeitamente dar conta da morfo-fonologia do romeno, o signo mole “ " representando a palatalização final das consoantes:

Иванович/Ivanovič é transliterado como Ivanovici (4 sílabas e não 5!), луп / лупь $\{\operatorname{lup}-\varnothing\}$

$$
\{\text { lup'-ø\} }
$$

Enquanto o alfabeto latino representa a oposição entre o singular e o plural dos substantivos por um grafema vocálico:

$$
\begin{aligned}
& \text { lup - lupi } \quad\{\text { lup-ø }\} \\
& \text { \{lup-i\} }
\end{aligned}
$$

Ao contrário, do ponto de vista etimológico, é o alfabeto latim que mantém a transparência da composição morfemática, apagada em cirílico. O problema da escolha entre dois princípios é recorrente na maioria das mudanças de alfabeto na Europa oriental.

\section{Marr, Stalin e a língua moldava}

Em 20 de junho de 1950, ocorreu um acontecimento fundamental na linguística soviética. Em um longo artigo no jornal Pravda, J. Stalin acabou com o que havia sido o

27 Lei relativa à volta da língua moldava à grafia latina (Lege cu privirea la revenirea limbii moldoveneşti la grafia latină) (n 3462 de 31/08/1989): “A passagem da língua moldava, falar de origem e estrutura românicas, ao alfabeto usual latim, baseia-se no caráter mais adequado, reconhecido pela ciência, do alfabeto latim para figurar a fonética e a gramática desse falar; está de acordo às reivindicações dos cidadãos da república e visa contribuir a eliminar as deformações produzidas na língua, por uma série de causas objetivas e subjetivas, e revelar o nível de cultura linguística do povo moldavo, assim como a influência das fontes científicas, éticas, morais, culturais, psicológicas, pedagógicas e sociais, no desenvolvimento da língua moldava." 
dogma obrigatório dos princípios do marrismo ${ }^{28}$. As consequências, para a língua moldava, foram consideráveis. O conteúdo do artigo era surpreendente, pois os marristas e os linguistas estalinianos compartilhavam o mesmo duplo postulado, segundo o qual 1) a língua moldava não era romena; 2) a língua tem um conteúdo.

Assim como a teologia cátara só é conhecida através dos autos da Inquisição, a visão marrista da língua moldava muitas vezes só é conhecida através das inúmeras "críticas", relatos negativos e impiedosos feitos por seus adversários ou por aqueles que se tornaram seus antagonistas após a intervenção de Stalin. O que podemos hoje reconstituir da contribuição marrista à questão da língua moldava poderia se resumir a duas posições mutuamente contraditórias:

1. As similitudes entre as línguas não provêm de um ancestral comum, mas de um "processo glotogônico único", que faz as línguas evoluírem por saltos bruscos, em uma ordem de sucessão tipológica idêntica e necessária para todas as línguas, em função das mudanças na base socioeconômica. A língua é portanto uma superestrutura e, portanto, o moldavo e o romeno não têm ancestral comum.

2. As línguas evoluem não por diferenciação, mas por hibridação, a qual se deve ao contato. Portanto, ou o moldavo é uma língua romano-eslava, ou é uma língua inteiramente eslava.

Stalin refutou o segundo ponto e isso suscitou dificuldades específicas para a língua moldava, pois um dos objetivos de Stalin era de afirmar a supremacia da língua russa nos seus contatos com as outras línguas.

Seria absolutamente incorreto acreditar que o cruzamento de duas línguas pode, por exemplo, produzir uma nova, terceira língua, que não se pareceria com nenhuma das línguas cruzadas, distinguido-se qualitativamente de cada uma delas. Na realidade, uma das línguas sai geralmente vitoriosa de tal cruzamento, conservando seu sistema gramatical, seu fundo lexical de base e continuando a evoluir segundo as leis internas de seu desenvolvimento, enquanto a outra língua, aos poucos, perde sua qualidade e definha gradualmente. [...]

Foi o caso, por exemplo, do russo, com o qual, durante o desenvolvimento histórico, cruzaram-se as línguas de outros povos e que sempre se manteve vitorioso (Staline 1950, trad. fr. in Gadet et al., 1979:215-216).

Contudo, se o russo, nos seus contatos com outras línguas, "sempre se manteve vitorioso", como se explica que o moldavo, apesar de ser tão fortemente "influenciado pelo russo", permaneceu idêntico a si mesmo e que, nem por isso, o russo "definhou"? Stalin provavelmente não previra essa objeção mas, a partir de então, o trabalho de equilibristas dos linguistas soviéticos, que escreviam a respeito da língua moldava, consistiria a manter as duas posições antitéticas, ao mesmo tempo que afirmavam seguir à risca o texto de Staline, em nome da introdução do marxismo na Linguística. E foi ali que interveio a suposta diferença entre hibridação e influência (sempre valorizada enquanto "frutífe-

28 Muitas perguntas foram levantadas em relação ao autor real deste texto. Hoje, desde as pesquisas do historiador Ilizarov, que trabalhou nos arquivos pessoais de Stalin e estudou os diversos rascunhos desse texto, elaborados após conversas com os linguistas V. Vinogradov et A. Čikobava. V. Ilizarov, 2012, ficou comprovado que foi mesmo Josef Stalin que o escreveu. 
ra e enriquecedora" $)^{29}$, pois ela não questionava as "leis internas do desenvolvimento". Não sendo a língua uma superestrutura, seu núcleo mantém-se inalterado durante sua evolução. Isso permite afirmar em relação ao moldavo "sua constância [ustojčivost'] e sua resistência a todas as tentativas violentas de assimilação" (Ceban 195: 10) e enfatizar que o contato estreito com as línguas eslavas do Leste inscreve-se perfeitamente na sua especificidade intrínseca:

[É preciso] observar a especificidade, a originalidade e as leis internas de evolução da língua moldava, enfatizar suas particularidades e seu caráter próprio, assim como a união íntima [sočetanie] dos elementos românicos e eslavos que nela se manifesta. É preciso suprimir tudo aquilo que é artificialmente emprestado, tudo aquilo que não corresponde às leis internas da língua moldava. (Ceban 1951:15)

A fórmula " $a$ mas não- $a$ " permite ir contra a corrente do dogma estaliniano sem que isso seja muito perceptível: o moldavo não é uma língua hibridizada com o russo, mas ele apresenta uma forte influência do russo:

A estabilidade da estrutura gramatical (morfologia) do moldavo [...] não exclui uma influência externa, nem supõe sua impermeabilidade. Tanto que, por exemplo, traços de origem eslava penetraram no sistema românico do verbo moldavo. (Vartician 1951:46)

Quando, ao falar da estabilidade da estrutura gramatical do moldavo, se afirma que ele é românico, isso não subentende, de modo algum, que, por ser sua estrutura românica, o moldavo deva aperfeiçoar-se e enriquecer-se apenas a partir de elementos linguísticos românicos. Nessa questão, não pode haver duas opiniões diferentes. È preciso proteger, como a menina dos nossos olhos, a pureza cristalina da língua da nação socialista moldava, de qualquer influência ou aportes estrangeiros. A língua moldava pode e deve enriquecer-se e fortalecer-se graças à influência da língua do povo mais avançado e esse povo é o grande povo russo da época soviética. Os elementos linguísticos russos tornam as línguas da União Soviética, incluindo a do povo moldavo, mais fortes, expressivas e ricas. (ib.: 51)

A dupla coação é constante no discurso dos linguistas soviéticos que tentam aplicar os preceitos stalinianos à situação moldava. Esses afirmam que a língua é estável mas, ao mesmo tempo, ela muda constantemente. Suas incessantes citações do texto escrito pelo "corifeu da ciência” lhes permitem manter posições ambíguas, reforçadas por princípios tão vagos que podem ser distorcidos à vontade:

Em caso de contatos, não surge uma terceira língua. Não há uma fusão, mas apenas um movimento de ajuste, de acomodação [osedanie] de alguns elementos, que, aliás, não envolve os setores fundamentais da língua que venceu. (Šišmarev 1952: 84)

No entanto, J. Stalin ensina que 'diferentemente da superestrutura, que não está diretamente ligada à base, mas apenas através da economia, a língua é diretamente vinculada à atividade produtora do ser humano' (Staline, 1950, p. 24) [...]. É por isso que a componente lexical da língua, a mais sensível, encontra-se em um estado de mudança contínua.

29 "A língua russa foi para o moldavo, assim como para as outras línguas da União soviética, uma fonte vivificadora, de criação de novas palavras, necessárias à nova sociedade socialista.” (Mixal'či 1953: 61). 
[...] ' O desenvolvimento do comércio, que necessita de uma correspondência muito bem regulada, o nascimento da impressão, o desenvolvimento da literatura, tudo isso provocou profundas mudanças na evolução da língua'. (Staline, ib., p. 26) [...] (Ceban 1951: 9-10)

Essa negação naturalista da hibridação das línguas teve consequências surpreendentes no estatuto do moldavo. De fato, a posição marrista, segundo a qual "o moldavo é uma língua híbrida romano-eslava" ou até mesmo "o moldavo tornou-se uma língua eslava" convinha perfeitamente ao discurso irredentista da RASSM nos anos 1930.

Assim como aconteceu na Transcarpácia e na Galícia, os habitantes da Moldávia falavam uma língua eslava do leste e precisavam portanto ser "reintegrados" ao território soviético (mesmo não tendo nunca sido parte da Rússia). Se o moldavo fosse uma língua híbrida românico-eslava ou totalmente eslava, a Bessarábia (ou a inteira Moldávia, incluindo a margem direita do Prut) deveria então ser integrada à União soviética.

Contudo, parte considerável do pathos anti-marrista dos anos 1950 diz respeito precisamente à recusa da hibridação. Assim sendo, o russo, dessa vez, não poderia mais "ter se mantido vitorioso", já que o moldavo, na sua base lexical e sua gramática, tinha permanecido inteiramente românico. Foi preciso então utilizar muita retórica para "demonstrar" que, se não houve hibridação moldavo-russo, houve uma influência preponderante do russo no moldavo. A diferença entre a hibridação e a influência era significativa e inseriu-se nas tendência naturalistas e imanentistas da linguística staliniana.

Em um artigo da prestigiosa revista Izvestija Akademii nauk, o linguista moldavo D. Mixal'či (Mihalci) apoiou-se em uma citação de Stalin - "segundo nos ensina J. Stalin, a estrutura gramatical e o fundo lexical de base de cada língua evoluem em função de suas leis internas" - para "demonstrar" que o moldavo possuía um fundo lexical de base e, portanto, não podia ser uma língua híbrida” (Mixal'či 1951:294). Foi aqui que apareceu a divergência fundamental com as posições marristas:

I. D. Čeban afirmava que a língua moldava era uma língua eslava e que seu processo de hibridação estava continuando. Ele duvidava de que o moldavo fosse de origem românica, atribuindo essa última opinião a 'fontes burguesas'. (Ib.:295)

É fácil compreender o quanto fosse difícil para os linguistas argumentar tendo que aplicar o raciocínio de Stalin ao par moldavo-russo Isto é, se "o russo sempre permaneceu a língua vitoriosa", mas o moldavo não se tornou uma língua eslava nem estava em processo de extinção, isso significava que o moldavo "ficara vitorioso" e não o russo. Dali o interesse em substituir o conceito de hibridação pelo de influencia e mostrar que o moldavo não era uma língua híbrida, apesar dos numerosos empréstimos ao russo (assim como o inglês não é uma língua híbrida porque sua gramática e seu fundo lexical de base são anglo-saxões). (cf. Staline 1950, trad. fr. in Gadet et al. 1979:207).

A linguística staliniana, nas suas grandes linhas, foi um retorno às posições clássicas dos neogramáticos. Contudo, no que diz respeito ao moldavo, ela se afastou dessas posições em um ponto: se não houve convergência de línguas diferentes por hibridação (posição marrista), não houve também, nesse caso, divergência a partir de um ancestral comum.

A posição romena foi unitarista: a língua do Principado de Valáquia e a do Principado de Moldávia eram duas variantes quase iguais de uma mesma língua, chamada moldo-valáquia. A seguir, quando da reunião dos dois principados em um Estado romeno, essa língua, constituída de uma simbiose dessas duas variantes, passou a ser chamada romena. 
A posição soviética, ao contrário, foi separatista: o que é e sempre foi, desde a origem, o moldavo, é diferente do romeno (em contradição com a tarefa de edificação de uma língua literária moldava). Note-se que os adversários dividiam um mesmo pressuposto romântico-positivista, a saber, que os objetos do conhecimento preexistem ao ato de investigação e, portanto, o procedimento discursivo consiste não a verificar uma hipótese, mas a reiterar afirmações ontológicas do tipo “ $x$ é $y$, e não $z$ ”. Dado que, nos dois casos acima, a história de uma língua é necessariamente a do povo que a fala, a controversa baseou-se na afirmação da existência de um certo povo. A posição soviética foi a de que o povo moldavo da RM era o mesmo que o do Principado de Moldavia do século XIV. Desse modo, o pertencimento étnico dos moldavos da Romênia tornou-se o grande não-dito, já que indizível, do discurso staliniano: seriam eles o mesmo povo que os Moldavos de Bessarábia e falariam a mesma língua? Dali decorreram os litígios a respeito dos escritores moldavos anteriores a 1812, reivindicados tanto pelos intelectuais romenos quanto pelos moldavos da RM como "os nossos", o que, do lado moldavo, significa "não os deles".

O texto de Stalin permite uma solução fixista e até mesmo essencialista, mas em nenhum caso evolucionista, para o problema da "essência da especificidade do moldavo". Por um lado, haveria uma continuidade essencial do moldavo através da história. Por outro, o romeno e o moldavo seriam línguas diferentes desde o início de sua existência, não sendo o produto de uma divergência a partir de um ancestral comum. Dessa visão decorrem as inúmeras pesquisas sobre a etnogênese do povo moldavo, das quais não trataremos aqui. O romeno seria portanto o resultado da evolução do valáquio, influenciado pelo búlgaro, ao passo que o moldavo "literário" da Bessarábia seria o descendente do moldavo escrito e falado no Principado de Moldávia, influenciado pelas línguas eslavas orientais - ucraniano e russo (v. Mixal'či 1953). Assim, a língua moldo-valáquia nunca teria existido, o que facilitava a sustentação da contradição acima assinalada - se a língua moldava permaneceu “estável” apesar de ter sido o produto de diversas épocas foi porque a separação foi inicial ${ }^{30}$.

Isso não quer dizer que as dificuldades diminuíram, pois permanecia inteiro o problema do estatuto da língua falada na Moldávia romena. Se os moldavos da Romênia falavam uma língua moldava (ao passo que sua "língua literária” era o romeno, isto é o valáquio), era preciso considerar que os moldavos constituíam um único povo, mas duas nações diferentes. $\mathrm{E}$ aqui entrava em jogo a noção de "conteúdo da língua". O moldavo da Bessarábia era uma língua literária (à diferença do moldavo da Moldávia romena, que não passava de um falar não padronizado). Além disso, o moldavo da Bessarábia possuía o conteúdo de uma nação socialista, segundo o princípio estaliniano proclamado no $\mathrm{XVI}^{\mathrm{o}}$ congresso do Partido em 1930, das "línguas (soviéticas) nacionais na forma e socialistas no conteúdo".

No que diz respeito à língua e à literatura, temos as tarefas urgentes de melhorar a ortografia e a gramática, enriquecer a língua literária, desembaraçá-la de todos os tipos de influências e sedimentos burgueses a elas estranhas e de desenvolver a dialetologia e a história da

30 Ver a seguir a declaração que o linguista não marrista, Sergievskij, fazia já em 1948 : “ A língua moldava, enquanto língua literária, chegou até nós através dos documentos escritos, ao menos desde o século XVI. Já antes dessa época, ela era a língua viva falada pela população do principado independente de Moldavia. Essa é a posição que ela ocupa hoje na RSSM. Ela possui sua própria história, apesar de sua grande proximidade com a língua do antigo principado de Valáquia. Após a formação da Romênia, ela passou a ser o fundamento da literatura e da língua nacional dessa última. Ela pode e deve ser estudada no seu desenvolvimento histórico, assim como qualquer outra língua da família das língua românicas" (Sergievskij 1948:35). 
língua e da literatura moldavas. (relação do secretário do Comité central do PC(b) da Moldavia Koval, 7 de fevereiro de 1949) citado por Mixal'či 1953:59.

Essa obsessão pela especificidade, pela originalidade intrínseca [samobytnost'] de uma nação, que seria comprovada pela sua língua, evoca necessariamente as teorias neo-humboldtianas, tão corriqueiras nos anos 1930 na Alemanha, que tendiam a refutar o universalismo do século das Luzes e as idéias da Revolução francesa:

[...] [e não] como na França do século XVIII, especulações sobre a capacidade que uma língua tem de expressar o pensamento, já que, a cada língua corresponde um pensamento específico e não uma capacidade de pensamento universal. (Mixal'či 1953:61)

Foram, de fato, as teorias romântico-positivistas do século século XIX, na Europa, que serviram de fundamento à lógica geopolítica do marxismo soviético staliniano. Isto é, o território de um povo e, portanto, de uma nação legítima e de um Estado, é onde sua língua é falada.

[...] o que, é claro, encontrou um reflexo lógico nas decisões históricas do Partido e nos atos oficiais do governo soviético, após o quais as terras do povo moldavo foram reunidas no Estado único da nação socialista moldava. (Vartician 1951:41)

O problema, a esse ponto, era saber se os moldavos da Romênia falavam a mesma língua que os da RSSM. É claro que, do lado soviético, expressar reivindicações irredentistas em uma parte do território de um Estado irmão constituía uma questão delicada. Daí a necessidade de afirmar, ao mesmo tempo, que a língua moldava era, desde o início, diferente da língua romena (que por sua vez constituía uma normalização do valáquio), e que o moldavo da Moldávia era a língua literária de uma nação, o que o falar moldavo romeno não era, já que não tinha passado do estado de dialeto não normatizado, "por ter sido esmagado [peremalyvanie] pela língua literária nacional romena” (Boršč 1951:131), apesar de ter sido no passado a língua literária de um Estado independente, independente até 1859, com uma literatura clássica "mais rica que a literatura valáquia" (Vartician 1951 : 41).

A linguística estaliniana, romântico-positivista, em nome do marxismo-leninismo, foi ao mesmo tempo naturalista e dirigista. Preconizava, por um lado, que uma língua tem leis internas; por outro, que é preciso aperfeiçoá-las. Por um lado, considerava que é preciso aprender com o povo, por outro, que é preciso educar o povo. A noção-chave, verdadeira denegação da "intervenção consciente na língua", era que o processo é "orgânico" e não "mecânico", ou seja, artificial.

"[As diferenças] são numericamente suficientes para se convencer que as duas línguas, o romeno e o moldavo, evoluem segundo suas próprias leis internas de desenvolvimento, que determinam a especificidade e individualidade nacionais de cada uma delas. O papel fundamental da ciência linguística soviética e de seus pesquisadores é precisamente de colocar essas leis em evidência”. (Vartician 1951:45)

"[é preciso se apoiar sobre], primeiro, a autoridade do próprio povo, com seu uso espontâneo, sem artifício [bezyskusstvennyj], segundo, a dos escritores que representam a vida espiritual do povo." (Ceban 1951:34) 


\section{O caso Jakobson}

Seria incorreto circunscrever as discussões sobre a língua, na Europa oriental, no período entre as duas guerras mundiais, a um território fechado sobre si próprio, fora do mundo exterior. A linguística soviética participava plenamente das principais correntes de pensamento de seu tempo, apesar de suas denegações.

É possível ser um grande linguista, reconhecido universalmente como tal, e estar envolvido na ideologia dominante de seu tempo. Jakobson, personagem complexo, funcionário da missão diplomática soviética em Praga até 1929, não escondia suas simpatias pela ideia imperial da União Soviética, que, através de raciocínios científicos, ele procurava fundamentar "na natureza". ${ }^{31}$

Por volta de 1929-1931, Jakobson estava à procura da fronteira ideal que separaria a "Eurásia" da Europa. Ao fazer isso, ele inscrevia-se perfeitamente na grande obsessão dos intelectuais russos, desde a época de Pedro o Grande, uma inquietação fundamental que consistia em procurar ser si mesmo ao mesmo tempo que se imitava o Outro.

Para o Jakobson fonólogo, era o trato distintivo, fonológico, da palatalização das consoantes, associado à ausência de politonalidade, que caracterizava a Eurásia enquanto território formado por uma "união de línguas ${ }^{32}$ ". Ele tinha a todo custo que comprovar essa tese. Na época, o Jakobson-emigrado não podia mais ser um pesquisador de campo. Ele tinha que trabalhar com material de segunda mão, atlas e descrições de viajantes. Para a região-“fronteira" que nos interessa aqui, ele utilizou duas fontes:

- $\quad$ G. Weigand: Linguistischer Atlas des Dacorumanischen Sprachgebietes (Leipzig, 1909) e

- M.V. Sergievskij: "Materialy dlja izučenija živyx moldavskix govorov na territorii SSSR" [Matériais para o estudo dos falares vivos moldavos no território soviético], Učenye zapiski Instituta jazyka i literatury, I, Moskva, 1927: 73-97.

O credo fonológico de Jakobson era claro e ele o expôs, em várias ocasiões entre os anos 1920 e 1930, em francês, na revista parisiense Le Monde slave: "nenhuma das línguas românicas apresenta o fenômeno da palatalização, à exceção do moldavo, isto é, do representante oriental do grupo romeno" (Jakobson 1931b:373), e também em russo, nas brochuras eurasistas:

A oposição das consoantes em função de sua palatalização ou de sua dureza é profundamente estranha às línguas românicas do oeste. [...] [i șẹpiS Somente o grupo romeno, ilha linguística extrema-oriental do mundo românico, conhece a correlação da palatalização das consoantes. A parte oriental dessa ilha linguística é ocupada pela língua moldava. Os Carpatos constituem a fronteira ocidental da língua moldava e a República soviética de Moldávia, sua fronteira oriental (cf. Weigand 1909, p.10 e mapa 65). Um trabalho de larga escala (Sergievskij, 1927) é dedicado aos falares da República de Moldávia. A língua

31 Em “Slavische Sprachfragen in der Sovjetunion”, Slavische Rundschau, 1934-n $1324-343$, ele protesta de forma veemente contra o "chauvinismo local" e o "separatismo cultural" dos lingüistas ucranianos e bielorussos (ibid.,p.334) e aprova inteiramente a política linguística soviética que consistia em "aproximar" essas duas línguas do russo. "Foram eliminados alguns artifícios ortográficos absurdos, cujo único propósito era a criação de uma alienação [Entfremdung] artificial entre as escritas bielorussa e russa.

32 Ver Sériot $1997^{\mathrm{a}}, 1997$ c,1999 (1), 2012(2) 
moldava tem como característica a coincidência dos seguintes traços: 1) s' et z' suaves em todas as posições, 2) as oclusivas médias, combinação de p, b, + i não silábico (Weygand, p.12). Tudo leva a crer que, em alguns falares descritos por Sergievskij (região de Rybniza), t e d palatalizados confundiram-se com essas oclusivas. $\mathrm{O}$ autor escreve que 'do ponto de vista acústico, elas quase se confundem' e que 'em uma pronúncia individual, elas podem, de fato, confundir-se' (p.87). É preciso observar que, na escrita, os camponeses não diferenciam essas consoantes, apesar da ortografia corrente, e escrevem, por exemplo, май дини ар арди, considerando que, de acordo com o princípio etimológico, seria necessário escrever бине ар арде, е que Sergievskij propõe, como transcrição convencional $g$ 'in' $i$ ar ard 'i (p. 96). Nesses mesmos falares, s' e z' realizam-se em apicais palatalizadas. A julgar pelos exemplos dados por Sergievskij, pode-se encontrar na final: s', t', r' (ais' = roum. aici, zern' = roum. viermi, or' = roum. ori). Tanto essas consoantes quanto z', d' podem combinar-se com os fonemas a, o, e, i, mas as labiais macias podem fazê-lo apenas com e, i. (Jakobson 1931a, [1971:168])

Jakobson lança então uma afirmação que, para ele, tinha consequências fundamentais: A correlação de palatalização, própria dos falares moldavos e da língua literária moldava, é desconhecida no romeno literário ${ }^{33}$. À questão de saber em qual região do grupo romeno passa a fronteira da correlação de palatalização devem responder os especialistas de romenística, que podem, a partir das mais diversas indicações dialetológicas, calcular a sistematicidade fonológica dos falares romenos. No entanto, desde já, podemos dizer que, no que diz respeito à correlação fonológica de palatalização, o grupo romeno constitui um paralelismo à sucessão espacial dos dialetos búlgaros: de leste a oeste, essa correlação começa a decrescer, para a seguir desaparecer completamente. [ibid.]

Essas afirmações de Jakobson pedem alguns comentários, no que diz respeito à história e à epistemologia da linguística, em particular no campo da fonologia.

Em primeiro lugar, é necessário observar que Jakobson nunca questionou o fato de saber se ele está lidando com uma língua "literária", normatizada, padronizada ou um diassistema dialetal. Ele passava de uma à outro e coletava dados que pertenciam a duas ordens diferentes: por um lado, o continuum fonético e, por outro, o descontinuum fonológico, apesar dessa distinção ser precisamente a base de sua argumentação. Por outro lado, tratava-se de uma visão muito diferente da visão de Saussure. Não havia, em Jakobson, uma oposição entre a língua enquanto objeto construído pelo linguista e a língua na sua realidade empírica, preexistente à investigação (no sentido de "idioma"). Além disso, ele não apresentou nenhuma oposição de pares mínimos, que diferenciariam o moldavo do romeno.

O grande Jakobson, levado por suas simpatias políticas prosoviéticas, chegou a confundir a fonologia com a fonética... De fato, a maioria de suas afirmações dizem respeito à fonética e não à fonologia: "O sistema moldavo das vogais é muito parecido com o do russo literário" (Jakobson, 1931 [1971:168]).

Vinte anos mais tarde, os linguistas estalinianos seguem-lhe o passo, quando falam de

dois domínios linguísticos autônomos, claramente diferenciados: o moldavo e o valáquio, cada um apresentando particularidades fonético-morfológicas e léxico-semânticas bem distintas, tais como a palatalização das labiodentais antes das vogais anteriores em moldavo ${ }^{34}$ (Vartičan 1951:42).

33 [Evidenciado por mim];P.S

34 Vartičan trabalhou com um atlas dialetal publicado na Romênia em 1942. Tratam-se, de fato, de traços dialetais comuns ao moldavo da Bessarábia e ao moldavo da margem direita do Prut. 
No entanto, na época, a discussão a respeito da palatalização parecia não ser unânime, o problema sendo, mais uma vez, o contínuo linguístico dos dois lados da fronteira do Prut. Mixal'či criticava Ceban por opor a palatalização das consoantes em moldavo às normas de pronúncia do romeno, "esquecendo, desse modo, que essa pronúncia é idêntica em grande parte da atual República popular da Romênia: a Moldávia do outro lado do Prut" (Mixal'či 1953:59).

Jakobson envolveu-se em um inextricável emaranhado de contradições, que se justificam, em parte, pela novidade da ciência fonológica, recém nascida, mas também e sobretudo pelo extremo desafio ideológico e político do movimento eurasista, compartilhado por muitos intelectuais emigrados, que consistia em embasar uma representação do Estado em um saber científico e justificar uma fronteira política a partir de dados naturalistas. Foi nesse sentido que a novidade científica antipositivista proposta por Jakobson e Troubetzkoy encontrou-se em uma trágica tensão com os modos de pensamento naturalista, herdados do século XIX, de uma época positivista e cientista, onde se pensava que as línguas e os povos eram objetos naturais, como as plantas, o curso dos rios ou as cadeias montanhosas.

Mas de tanto querer provar, Jakobson e Troubetzkoy se viram arrastados em uma emaranhado de contradições do qual não podiam mais sair. De tanto querer fazer coincidir as fronteiras linguísticas e estatais, eles criaram seres estranhos, existentes apenas na sua imaginação, separando e reagrupando coletividades através da língua, do alfabeto, da religião, ignorando as solidariedades históricas e políticas. Quiseram tratar comunidades humanas e, portanto, sociais como objetos naturais. Sua busca das fronteiras naturais só serviu para confundir uma situação já complexa, esquecendo que se tratava de seres humanos e não de objetos.

\section{Conclusão}

Do ponto de vista ontológico, a pergunta "a língua moldava é o nome de quê?" não terá sentido enquanto não se precisar como é construído o referente do nome "língua", enquanto objeto de conhecimento. Língua materna, língua étnica (rodnoj jazyk), língua oficial, língua literária, língua dos escritores, língua do Estado, língua falada, língua do povo constituem construções discursivas que merecem uma definição precisa antes de serem utilizadas. todavia, no caso aqui discutido, a "língua moldava" é de fato uma entidade de geometria variável, cuja plasticidade permite as linhas argumentativas mais diversas e contraditórias, baseadas em três princípios distintos:

a) existem povos e cada povo é "portador" (nositel’35 de uma língua particular e é precisamente porque ele é portador de uma língua particular que ele é um povo.

b) para construir a língua literária, os intelectuais (escritores, poetas, gramáticos) devem apoiar-se na língua do povo.

c) para construir a língua literária, os intelectuais (escritores, poetas, gramáticos) devem incitar o povo a falar uma língua correta.

O primeiro princípio é positivista, o segundo é romântico, o terceiro poderia ser chamado de dirigista. Essa coexistência dos três princípios nas discussões sobre a língua na

35 A palavra russa nositel é o decalque do alemão Trãger. 
Europa oriental possui todas as características de um círculo infernal, onde a causa e a consequência tomam permanentemente o lugar uma da outra.

É, portanto, impossível responder à pergunta posta no título desse trabalho. Seu enunciado coloca essa pergunta fora de qualquer valor de verdade e nisso reside o interesse desse discurso louco: ninguém pode dizer a partir de qual limiar (quantas palavras) duas línguas devem ser declaradas diferentes. Como diferenciar o mesmo e o outro?

No entanto, por outro lado, o funcionamento desse discurso sobre a língua evidencia problemas epistemológicos que dizem diretamente respeito à linguística. A saber, se as línguas não são entidades contabilizáveis, como podemos descrever esse objeto escorregadio, que escapa permanentemente à apreensão? Somente as línguas normatizadas, "gramatizadas" (para usar o termo de Sylvain Auroux) são suscetíveis de serem descritas como conjuntos fechados.

A língua moldava que "existe" de fato na mente dos que assim a chamam, é um princípio de afirmação identitária, menos um instrumento de comunicação e mais um instrumento de comunhão, ao mesmo tempo que de não-comunhão, destinado a não ser compreendido por aquele do qual queremos nos diferenciar a todo custo para permanecer nós mesmos.

Portanto, a Moldávia não constitui uma singularidade. Ela é um caso extremo de uma situação corrente na Europa oriental, essa "outra Europa", onde a questão da língua, com a ajuda da ciência, é um dos aspectos - e não dos menores - de uma política de hegemonia e de insolúveis disputas territoriais, herdadas de um modo de pensamento que remonta ao século XIX.

Tradução: Florence Carboni, Ana Zandwais e Gilmar José Taufer Revisão: Florence Carboni e Ana Zandwais

\section{Referências}

ALEN GARABATO, Carmen (org.) La gestion des minorités linguistiques. Dans : L'Europe du XXI siécle. Limoges : Lambert-Lucas, 2013

BABEL, Anthony. La Bessarabie. Paris et Genéve : Felix Alcan, 1932

BEAUMONT, Fréderic. La frontière roumano-ukrainienne et le poids réel de la question de las minorités. Cybergeo, 2005

BELLET, Marc de. La Moldova : un nouvel état face à ses minorités et a ses voisins. Dans : Nationalismes en Europe centrale et orientale : conflits ou nouvelles cohabitations ? ALIGISAKIS, M et alii (orgs.), Genève : Institut européen,Georg Edit, 1997, p.87-117.

BERNAZ, Oleg. Identité nationale et politique de la langue, Une analyse foucaldienne du cas moldave. Berne : Peter Lang, 2016.

BERNšTEIN, Samuil. Grammatika rumynskogo jazyka. Predislovie k russkomu izdaniju. [Grammaire du romain. Préface a l'édition russe] Moskva : Izdatel'stvo inostrannoj literatury, 1950 .

BOCHMANN, Klaus. Quand les minorités mettent en question la stabilité de l'Etat. Le cas de la république de Moldavie. Dans : GABARATO, Carmen Alen. La gestion des minorités linguistiques dans l'Europe du xx siècle. Limoges : Lambert-Lucas, 2013, p.25-33.

BOGDAN, L. Istoriografia românā si problemele ei actuale. Bucaresti: Aca. Rom., Discurs, XXVII. 
BRUCHIS, Michael. One step back, two steps forward: on the language policy of the communist party of the soviet union in the national republics boulder (Co). East European Monographs, 1982.

. The republic of Moldavia. From the collapse of soviet empire to the restoration of the Russian empire. New York: Columbia University Press, 1996.

BUDAGOV, Ruben. Blizkorodstvennye jazyki i nekotorye osobennosti ix izucenija. [Les langues étroitement apparentées et quelques particularités de leur étude]. Dans : Tipologija sxodstv i razlicij blizkorodstvennyx jazykov [Typologie des similitudes et différences entre langues étroitement apparentées], Kišinev, Štiinca 1976, p. 3-8.

CARATINI, Roger. Dictionnaire des nationalités et des minorités de l'ex-URSS. Paris : Larousse, 1992.

CAZACU, Matei; TRIFON, Nicola. La République de Moldavie. Paris : Editions Non Lieu, 2010.

CEBAN, I. Nasušcnye voprosy moldavskogo jazyka v svete trudov I.V. Stalina. [Questions essentielles sur la langue moldave à la lumière des travaux de J. Staline]. Dans : Voprosy moldavskogo jazyka v svete trudov I.V. Stalina. Kišinev, Škoala sovetikè, 1951, p. 5-35. (en ligne)

CINCLEI, Grigore. Les notions de langue et nation roumaines à l'Est du Prout. Dans : SÉRIOT, Patrick (dir.). Cahiers de l'ILSL), $\mathrm{n}^{\circ} 8$, Langue et nation en Europe centrale et orientale du XVIII e siècle à nos jours, Lausanne : 1996, p. 75-92.

CHIOR, (K’or) P. Préface à L. Madan, Gramatika limbij moldoveně̌t' [Grammaire de la langue moldave], Tirašpolja : (Tiraspol'), ECM : 1929, p. III-X.

COSERIU, Eugen. Identitatea limbii si poporului român [L'identité de la langue et du peuple roumains], Limba româna : $n^{\circ} 10,2002$, p. 2-3.

DAMIAN, Angela. Qui sommes-nous ? De l'identité collective à la construction nationale. Dans : DURANDIN, Catherine Durandin; GRIDAN, Irina. Moldavie : repères et perspectives. Paris : L'Harmattan, 2017 (en ligne)

DIACONESCU, E. Românii din R.s.rit [Les Roumains orientaux], Iasi, Transnistria (sans indication d'éditeur), 1942.

DRESSLER, Wanda (dir). Le Second Printemps des nations, Bruxelles : Bruylant, 1999. DRWESKI, Bruno. L'espace Baltique - Mer noire. Strates : $\mathrm{n}^{\circ}$ 12, 2006, p. 157-176.

DURANDIN, Catherine; GRIDAN, Irina. Moldavie : repères et perspectives, Paris : L'Harmattan, 2017 (en ligne)

DYER, Donald L. The Making of the Moldavian Language. Studies in Moldovan: The History, Culture, Language and Contemporary Politics of the People of Moldova. Boulder (CO), East European Monographs, 1996, p. 89-108.

"Some influences of Russian on the romanian of Moldova during the soviet period.

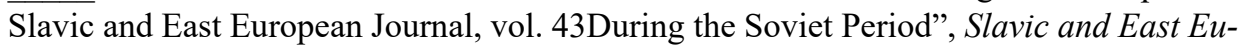
ropean Journal, vol. 43, $\mathrm{n}^{\circ}$ 1, 1999,p. 85-98.

FREGE, Gottlob. Über Sinn und Bedeutung., Zeitschrift für Philosophie und philosophische Kritik, $\mathrm{n}^{\circ} 100$, , 1892, p. 25-50.

GADET, Françoise; GAYMAN, Jean-Marc; MIGNOT, Yvan; ROUDINESCO, Elisabeth. Les Maîtres de la langue. Paris : Maspero, 1979.

; SÉRIOT, Patrick (dir.), Jakobson entre l'Est et l'Ouest, 1915-1939. Cahiers de

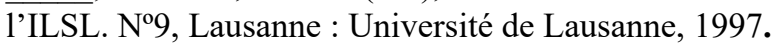

GLYN LEWIS, E. Multilingualism in the Soviet Union, The Hague: Mouton, 1972. 
GRANDE, Bension, 1936, Jazykovoe stroitel'stvo moldavskoj ASSR [L'édification linguistique de la République autonome socialiste soviétique de Moldavie], Revoljucija $i$ pis'mennost', n 2, Moskva, ., 1972, p. 177-179. (en ligne)

GRENOBLE, Lenore. Language Policy in the Soviet Union, Dordecht : Kluwer, 2003. ILIZAROV, Boris. Pocetnyj akademik Stalin i akademik Marr [L'académicien honoraire Staline et l'académicien Marr], Moskva: Vece, , 2012.

JAKOBSON, Roman. K xarakteristike evrazijskogo jazykovogo sojuza [Sur l'union eurasienne de langues], Pariž (Paris), Izdatel'stvo evrazijcev, 1931a.

Les unions phonologiques de langues . Le Monde slave, $\mathrm{n}^{\circ}$ 1, , 1931b, p. 371-378.

Slavische Sprachfragen in der Sovjetunion., Slavische Rundschau, $\mathrm{n}^{\circ} 1,1934, \mathrm{p}$. 324-343. (en ligne)

Sur la théorie des affinités phonologiques entre les langues. Actes du IV congrès international de linguistes (Copenhague1936), cité d'après Selected Writings I. The Hague : Mouton : 1971, p.234-246.

KAMUSELLA, Tomasz. Creating Languages in Central Europe during the Last Millenium. New York: Palgrave Macmillan, 2015.

KAZAZIS, Kostas. "How Non-Rumanian Is 'Moldavian?"' (Papers from the Second Conference on the Non-Slavic Languages of the USSR). Folia Slavica. Columbus: Slavica, v. 5, n 1-3, 1982, p. 224-229.

KING, Charles. "Moldovan Identity and the Politics of Pan-Romanianism", Slavic Review, v. 53, n 2, 1994, p. 345-368

. La Construction de la nation moldave. Oxford: Oxford University Press, 1995.

(en ligne)

. «Politique panroumaine et identité moldove », Balkanologie, v. I, n 1, Paris,.

. "The Ambivalence of Authenticity, or How the Moldovan Language Was Made",

Slavic Review, v. 58, n 1, 1999, University of Illinois, p. 117-142

KLEß, Arnold. „Rumänisch und moldauisch"e, Osteuropa, v. 5, fasc. 4, 1955, p. 281284.

LISICKIJ, V., « Nasuščnye voprosy istoričeskoj fonetiki moldavskogo jazyka » [Questions essentielles de phonétique historique du moldave], Voprosy jazykoznanija, $\mathrm{n}^{\circ} 1$, 1954, p. 84-96

LAZAREV, A., Moldavskaja sovetskaja gosudarstvennost'i bessarabskij vopros

[Le statut étatique de la Moldavie soviétique et la question bessarabienne], Kišinev :

Chişinău, 1974.

LENŢA, Anatol. «L'invention de la langue moldave à l'époque soviétique » Dans :

SÉRIOT, Patrick Sériot; TABOURET-KELLER, Andrée (dir.). Cahiers de l'ILSL. Le discours sur la langue sous les pouvoirs autoritaires, 2004, n 17, p. 115-134.

Le PAGE, R. P. The National Language Question. Oxford: Oxford University Press, 1964.

MADAN, L.,, Gramatika limbij moldovenešt' [Grammaire de la langue moldave], Tirašpolja (Tiraspol'): ECM, 1929. (en ligne : Préface).

MARR, Nikolaj. « Iz pereživanij doistoričeskogo naselenija Evropy, plemennyx ili klassovyx, v russkoj reči i toponimike » [Les traces de la population préhistorique de l'Europe (tribus ou classes) Dans : la langue et la toponymie russes, 1926. . Izbrannye raboty [Cuvres choisies], t. V, Etno- $i$ glottogonija Vostočnoj Evropy

[Ethno- et glottogonie de l'Europe orientale], Moskva-Leningrad: Gosudarstvennoe 
social'no-èkonomičeskoe izdatel'stvo, 1935. Čeboksary, Čuvašskij gosizdat, repris dans Marr, Izbrannye raboty, t. V, Moskva-Leningrad: Gosudarstvennoe social'noèkonomičeskoe izdatel'stvo, , p. 310-322, 1935.

MARTONNE, Emmanuel de. «Choses vues en Bessarabie ». La Revue de Paris, t. V, sept.-oct., 1919, p. 499-534. (en ligne)

MULLEN, James. 1989, “Is There a Moldavian language?”, Irish Slavonic Studies, n ${ }^{\circ}$ 10, p. 47-62.

NEGURA, Petru., «L'Union des Écrivains moldaves à l'époque jdanovienne : de la répression à la violence symbolique », Sociétés \& Représentations, n 15, 2003, p. 325343.

PILLON, Michel. «Les Daces, Trajan et les origines du peuple roumain : aspects et étapes d'une controverse européenne », Anabases, n 1, 2005, p. 75-104. (en ligne) PIOTROVSKIJ, R.G., [compte-rendu de] Sbornik 'Voprosy moldavskogo jazyka v svete trudov IV. Stalina' [Les questions de la langue moldave à la lumière des travaux de J. Staline], Voprosy jazykoznanija, n¹, 1952, p. 149-154. (en ligne)

. «Slavjano-moldavskie jazykovye otnošenija i voprosy nacional'noj specifiki moldavskogo jazyka » [Les relations linguistiques slavo-moldaves et les questions de la spécificité nationale de la langue moldave]. Dans ŠIŠMAREV, Vladimir ; V.P. Suxotin, D.E. Mixal'či (dir.), Voprosy moldavskogo jazkoznanija [Questions de linguistique moldave], Moskva : Izdatel'stvo Akademii nauk, p. 135-149, 1953.

RENAN, Ernest. Qu'est-ce qu'une nation?. Paris : Press Pocket, 1992. coll. Agora [1 $1^{\text {èr }}$ éd. : Association scientifique de France, Bulletin hebdomadaire, 26 mars 1882]. (en ligne) QUINET, Edgard. Les Roumains, Paris : Germer-Baillière, 1856.

SAUSSURE, Ferdinand de. (1 ${ }^{\mathrm{re}}$ éd. 1916), Cours de linguistique générale, Paris : Payot, 1979.

SEREBRENNIKOV, Boris. « Problemy sravnitel'no-istoričeskogo izučenija jazykov i voprosy moldavskogo jazykoznanija » [L'étude historico-comparative des langues et les questions de linguistique moldave]. Dans : ŠIŠMAREV, Vladimir, V.P. Suxotin, D.E. Mixal'či (dir.), Voprosy moldavskogo jazkoznanija [Questions de linguistique moldave], Moskva : Izdatel'stvo Akademii nauk, p. 34-53, 1953.

SERGIEVSKIJ, Maksim. « Materialy dlja izučenija živyx moldavskix govorov na territorii SSSR » [Matériaux pour l'étude des parlers vivants moldaves sur le territoire soviétique]. Učenye zapiski Instituta jazyka i literatury, t. I, Moskva, 1927, p. 73-97. . « Moldavskie ètjudy » [Etudes moldaves], Trudy Moskovskogo instituta istorii, filosofii i literatury [Travaux de l'Institut moscovite d'histoire, philosophie et littérature]. Moskva, v. V, 1939, p. 175-210.

. «Toponimija Bessarabii i ee svidetel'stvo o processe zaselenija territorii » [La toponymie de la Bessarabie et son témoignage sur le processus de peuplement du territoire]. Izvestija Akademii nauk, Otdelenie literatury i jazyka [Nouvelles de l'Académie des sciences, Section de littérature et langue], n 4, 1946, p. 333-350. (en ligne)

. «Problema proisxoždenija i razvitija moldavskogo jazyka v svete jazykoznanija » [Le problème de l'origine et de l'évolution de la langue moldave à la lumière de la linguistique]. Učenye zapiski Instituta istorii, jazyka i literatury Moldavskoj naučnoissledovatel'skoj Bazy Akademii nauk SSSR [Notes scientifiques de l'Institut d'histoire, langue et littérature de la base moldave de recherche scientifique de l'Académie des sciences de l'URSS], t. 1, Kišinev, 1948. 
SÉRIOT, Patrick. «L'un et le multiple : l'objet-langue dans la politique linguistique soviétique », États de langue (Encyclopédie Diderot), Paris : Fayard, p. 118-157, 1986. (en ligne)

. « Rome, Byzance et la politique de la langue en URSS », Cahiers du Monde russe et soviétique, t. XXIX, n 3-4, juillet-décembre, 1988, p. 567-574. (en ligne) " Linguistique nationale ou linguistique nationaliste ». Dans NIQUEUX, Michel (dir.), La Question russe. Essais sur le nationalisme russe, Paris : éditions Universitaires, 1992, p. 115-130.

« Nations et nationalités en U.R.S.S./C.E.I. Dans : SAINT-OUEN, François (dir.), Dictionnaire international du fédéralisme. Bruxelles : Bruylant, 1994, p. 413-416. (en ligne)

. Des éléments systémiques qui sautent les barrières des systèmes Dans :

GADET, Françoise ; SÉRIOT, Patrick (dir.), Cahiers de l'ILSL, Jakobson entre l'Est et l'Ouest, 1915-1939, n 9, Lausanne, 1997a: p. 213-236. (en ligne)

. «Faut-il que les langues aient un nom? Le cas du macédonien ». Dans : TABOURET-KELLER, Andrée (dir.), Le nom des langues. Les enjeux de la nomination des langues. Louvain : Peeters, 1997b, p. 167-190. (en ligne)

. «Ethnos et demos : la construction discursive de l'identité collective», Langage et Société, $\mathrm{n}^{\circ} 79,1997 \mathrm{c}, \mathrm{p} .39-52$. (en ligne)

. Structure et totalité. Les origines intellectuelles du structuralisme en Europe centrale et orientale, Paris : Puf, 1999. [2 éd. Limoges: Lambert-Lucas, 2012].

. "De la géolinguistique à la géopolitique : Jakobson et la 'langue moldave' ", Probleme de lingvistică generală şi romanică. Chişinău, vol. 1, 2003, p. 248-261. (en ligne)

. «La pensée ethniciste en URSS et en Russie post-soviétique », Strates, $\mathrm{n}^{\circ} 12$,

2005a, p. 111-125. (en ligne)

. «Inventer l'autre pour être soi : l'instrumentalisation de la linguistique en exYougoslavie ». Dans VARRO, Gabrielle (dir.), Regards croisés sur l'ex-Yougoslavie, Paris : L'Harmattan, 2005b, p. 189-198. (en ligne)

SÉRIOT, Patrick ; CAUSSAT, Pierre ; NORMAND Claudine. « Langue et nation : une relation problématique ». Dans : SÉRIOT, Patrick (dir.), Cahiers de l'ILSL, n 8, 1996, Langue et nation en Europe centrale et orientale du XVIIIème siècle à nos jours, $\mathrm{p}$.

I-VI. (en ligne)

SÉRIOT, Patrick ; TABOURET-KELLER, Andrée. (dir.), Cahiers de l'ILSL, ${ }^{\circ}{ }^{17}$, Le discours sur la langue sous les pouvoirs autoritaires, Lausanne, 2004. STALIN, Losif. « Marksizm i nacional'nyj vopros » [Le marxisme et la question nationale], publié sous le titre : « Nacional'nyj vopros i social-demokratija » [La question nationale et la socialdémocratie], in Prosveščenie, $n^{\circ} 3,4,5,1913$. Repris sous le titre Nacional'nyj vopros $i$ marksizm, Sankt-Peterburg : Priboj, 1914. (en ligne)

Marksiszm i voprosy jazykoznanija [Le marxisme et les questions de linguistique], Moskva: Gosudarstvennoe izdatel'stvo političeskoj literatury, 1950. (en ligne). Dans : GADET, Françoise ; GAYMAN, Jean-Marc ; MIGNOT, Yvan Mignot ; ROUDINESCO, Elisabeth. Les maîtres de la langue, Paris : Maspero, p. 198-236, 1979.

ŠIŠMAREV, Vladimir (dir.). Voprosy moldavskogo jazkoznanija [Questions de linguistique moldave], Moskva : Izdatel'stvo Akademii nauk, 1953. 
. « Romanskie jazyki jugo-vostočnoj Evropy i nacional'nyj jazyk moldavskoj

$\overline{\mathrm{SSR}}$ » [Les langues romanes de l'Europe du Sud-Est et la langue nationale de la RSS de Moldavie]. Dans : ŠIŠMAREV, Vladimir ; V.P. Suxotin ; D.E. Mixal'či (dir.). Voprosy moldavskogo jazkoznanija [Questions de linguistique moldave], Moskva : Izdatel'stvo Akademii nauk, 1953, p. 73-120. (en ligne)

ŠIŠMAREV, Vladimir, SUXOTIN V.P., MIXAL'iČI, D.E. (dir.), 1953, Voprosy moldavskogo jazykoznanija [Question de linguistique moldave], Moskva : Akademija nauk SSSR.

TABOURET-KELLER, Andrée. (dir.), Le Nom des langues. Les enjeux de la nomination des langues, Louvain : Peeters, 1997

TRIFON, Nicolas. « La langue roumaine au cœur de la problématique de reconstruction nationale de la république de Moldavie ». Dans : DRESSLER, Wanda (dir.), Le second printemps des nations, Bruxelles : Bruylant, 1999, p. 257-281.

. « Retour sur une trouvaille stalinienne : la langue moldave », Au Sud de l'Est,

Paris : Editions Non lieu, $\mathrm{n}^{\circ}$ 3, 2007.

. «Guerre et paix des langues sur fond de malaise identitaire ». Dans : CAZACU,

Matei ; TRIFON, Nicolas. La République de Moldavie. Paris : Editions Non lieu, 2010, p. $167-268$.

QUINET, Edgard, CEuvres complètes : Les Roumains. Paris: Germer-Baillière, 1856. VARRO, Gabrielle (dir.). Regards croisés sur l'ex-Yougoslavi. Paris : L'Harmattan, 2005.

VARTICIAN, I. « K voprosu o grammatičeskom stroe moldavskogo jazyka v svete učenija I.V. Stalina o jazyke » [La question de la charpente grammaticale de la langue moldave à la lumière de l'enseignement de J. Staline sur la langue], in Voprosy moldavskogo jazyka v svete trudov I.V. Stalina, Kišinev : Škoala sovetikè, 1951, p. 36-51. (en ligne) VILCU-POUSTOVAIA, Irina. " 'Si je suis moldave, je parle moldave' ou 'je parle roumain, donc je suis roumain(e)'. Nommer sa langue », Education et sociétés plurilingues, $\mathrm{n}^{\circ} 1,1996$, p. 59-68.

VINOGRADOV, Viktor. « Osnovnye zadači sovetskoj nauki o jazyke v svete rabot I.V. Stalina po jazykoznaniju » [Les tâches principales de la science soviétique du langage à la lumière des travaux de J. Staline en linguistique]. Dans : ŠIŠMAREV, Vladimir, SUXOTIN V.P., MIXAL'iČI, D.E. (dir.), Voprosy moldavskogo jazykoznanija [Question de linguistique moldave], Moskva : Akademija nauk SSSR, p. 5-33, 1953. WEIGAND, Gustav., Linguistischer Atlas des Dacorumanischen Sprachgebietes, Leipzig, 1909.

Recebido em: 10/05/2019; Aceito em: 20/05/2019 